Canadian Science Publishing

Canadian Journal of Earth Sciences Revue canadienne des sciences de la Terre

\title{
Paleoclimate and precipitation seasonality of the Early Eocene McAbee megaflora, Kamloops Group, British Columbia.
}

\begin{tabular}{|r|l|}
\hline Journal: & Canadian Journal of Earth Sciences \\
\hline Manuscript ID & cjes-2015-0160.R3 \\
\hline Manuscript Type: & Article \\
\hline Date Submitted by the Author: & 22-Feb-2016 \\
\hline Keyword: List of Authors: & $\begin{array}{l}\text { Gushulak, Cale A.C.; Brandon University, Biology Department; University } \\
\text { of Western Ontario, Department of Earth Sciences } \\
\text { West, Christopher Kirk; University of Saskatchewan, Department of } \\
\text { Geological Sciences } \\
\text { Greenwood, David R.; Brandon University, Biology Department }\end{array}$ \\
\hline &
\end{tabular}

SCHOLARONE

Manuscripts 
1 Paleoclimate and precipitation seasonality of the Early Eocene McAbee megaflora,

2 Kamloops Group, British Columbia

3 Cale A.C. Gushulak, Christopher K. West and David R. Greenwood ${ }^{\mathrm{a}}$

4

5

6

8 Cale A.C. Gushulak ${ }^{\text {b }}$ and David R. Greenwood, Department of Biology, Brandon University,

$927018^{\text {th }}$ Street, Brandon, Manitoba, R7A 6A9, Canada

10 Christopher K. West, Department of Geological Sciences, University of Saskatchewan, 114

11 Science Place, Saskatoon, Saskatchewan, S7N 5E2, Canada

${ }^{a}$ Corresponding author: David R. Greenwood (e-mail: greenwoodd@brandonu.ca).

${ }^{b}$ Current address: Department of Earth Sciences, University of Western Ontario, London, Ontario, N6A 5B7, Canada, cgushula@uwo.ca 


\title{
Paleoclimate and precipitation seasonality of the Early Eocene McAbee megaflora,
}

\section{Kamloops Group, British Columbia}

\author{
Cale A.C. Gushulak, Christopher K. West and David R. Greenwood
}

Abstract: Early Eocene fossil floras from British Columbia are a rich resource for reconstructing western North American early Cenozoic climate. The best known of these floras reflect cooler $\left(\mathrm{MAT} \leq 15^{\circ} \mathrm{C}\right.$ ) upland forest communities in contrast to coeval (MAT $\geq 18^{\circ} \mathrm{C}$ ) forests in lowland western North American sites. Of particular interest is whether Early Eocene climates were monsoonal (highly seasonal precipitation). The McAbee site is a $52.9 \pm 0.83 \mathrm{Ma} 0.5 \mathrm{~km}$ outcrop of bedded lacustrine shale interbedded with volcanic ash. In this report two historical megaflora collections, that were collected independently from different stratigraphic levels and/or laterally separated by $\sim 100-200 \mathrm{~m}$ in the 1980s (US) and 2000s (BU) are investigated to: (1) assess whether they represent the same leaf population, (2) assess whether a combined collection yields more precise climate estimates, and (3) reconstruct paleoclimate to assess the character of regional Early Eocene precipitation seasonality. Combined, the two samples yielded 43 dicot leaf morphotypes. Analysis of leaf size distribution using ANOVA showed no difference between the 2 samples and they were combined for climate analysis. Climate analysis using leaf physiognomy agrees with previous estimates for McAbee and other regional megafloras, indicating a warm $\left(\right.$ MAT $\left.\sim 8-13^{\circ} \mathrm{C}\right)$, mild $\left(\mathrm{CMMT} \sim 5{ }^{\circ} \mathrm{C}\right)$, moist $\left(\mathrm{MAP}>100 \mathrm{~cm} \cdot \mathrm{a}^{-1}\right.$ ) but summer-wet, non-monsoonal climate. Additionally, we recommend that climate analyses derived from leaf fossils should be based on samples collected within a stratigraphically constrained quarry area to capture a snapshot of climate in time rather than time-averaged estimates derived from multiple quarry sites representing different stratigraphic levels within a fossil site. key words: paleobotany, Eocene, Okanagan Highlands, paleoclimate, precipitation seasonality 


\section{Introduction}

The Early Eocene was the warmest time of the Cenozoic, and includes a sustained period of warmth, the Early Eocene Climatic Optimum (EECO; 50-52 Ma; Zachos et al. 2008) with terrestrial Mean Annual Temperatures (MAT) in North America ranging from $9-24{ }^{\circ} \mathrm{C}$ and possibly as high as $35^{\circ} \mathrm{C}$ depending on the paleontological climate proxy used (Greenwood and Wing 1995; Greenwood et al. 2010; Huber and Caballero 2011; Schubert and Jahren 2011; West et al. 2015). Worldwide the environment was largely tropical during the Early Eocene with thermophilic organisms such as alligators and palms, and warm-wet climates extending into the Arctic (Greenwood et al. 2010; Eberle and Greenwood 2012; Eldrett et al. 2014). However, there appears to be two overall climate regimes: ever-wet, (consistent precipitation year round), and monsoonal (highly seasonal precipitation) (Schubert and Jahren 2011; Huber and Goldner 2012; West et al. 2015).

Early Eocene fossil floras from British Columbia and Washington State, coined the Okanagan Highlands, provide a window into the climate of the Early Eocene at mid-latitudes (e.g., Smith et al. 2010, 2012; Archibald et al. 2011, 2014), where modelling has identified highly seasonal precipitation in the North American continental interior and ever-wet regimes on the west coast and adjoining area of British Columbia (Huber and Goldner 2012). The southern Okanagan Highlands sites are 200-300 km inland today (Fig. 1) with a dry climate (annual precipitation $<40 \mathrm{~cm} \cdot \mathrm{a}^{-1}$; e.g., climate normals for Kamloops $\left(28 \mathrm{~cm} \cdot \mathrm{a}^{-1}\right)$, Merritt $\left(32 \mathrm{~cm} \cdot \mathrm{a}^{-1}\right)$ and Princeton BC (35 cm. $\left.\mathrm{a}^{-1}\right)$ from Environment Canada, http://climate.weather.gc.ca/climate_normals/index_e.html). In the Early Eocene the Okanagan Highlands fossil sites are reconstructed as upland floras with paleoelevations around $0.8-1.3 \mathrm{~km}$ or higher (Wolfe et al. 1998; Tribe 2005; Smith et al. 2009). The Okanagan Highlands Early 
59 Eocene fossil assemblages are characterized by a mix of temperate and tropical organisms as 60 opposed to the predominantly tropical floras found in coeval lowland sites of the Chuckanut and 61 Huntingdon formations (Mustoe and Gannaway 1997; Archibald and Farrell 2003; Archibald et 62 al. 2011; Breedslovetrout et al. 2013; Eberle et al. 2014; Mathewes et al. this volume). The 63 Okanagan Highlands floras have been interpreted as being analogous to modern day highland 64 forests of Central America in which climate and vegetation become increasingly temperate as 65 elevation increases (Greenwood et al. 2005; Moss et al. 2005; Smith et al. 2012; Mathewes et al. 66 this volume).

Paleoclimate has been studied at several British Columbia Early Eocene sites with MAT 68 estimates ranging from $10-15^{\circ} \mathrm{C}$ (Archibald and Mathewes 2000; Greenwood et al. 2005; Smith et al. 2009, 2012; Dillhoff et al. 2013; Mathewes et al. this volume). The winters have been 70 interpreted from both plant and insect proxies as mild and frost free with Cold Month Mean 71 Temperature (CMMT) estimates for these sites ranging from $0-5{ }^{\circ} \mathrm{C}$, to perhaps as high as $8^{\circ} \mathrm{C}$ 72 (Greenwood et al. 2005; Moss et al. 2005; Dillhoff et al. 2013; Archibald et al. 2014; Mathewes 73 et al. this volume). Precipitation estimates based on nearest living relatives and leaf 74 physiognomy have been used to reconstruct Mean Annual Precipitation (MAP) over $100 \mathrm{~cm} . \mathrm{a}^{-1}$ 75 for most of the Okanagan Highlands floras (Greenwood et al. 2005; Smith et al. 2012; Dillhoff et 76 al. 2013; Mathewes et al. this volume). Overall, the climate of the Okanagan Highlands area 77 during the Early Eocene has been described as upper microthermal to lower mesothermal with mesic humid conditions (Moss et al. 2005; Smith et al. 2009, 2012; Dillhoff et al. 2013;

79 Mathewes et al. this volume). It is unknown, however, whether Early Eocene climate for the 80 Okanagan Highlands, including that of McAbee, was ever-wet or monsoonal. 
West et al. (2015) defined a summer monsoon for the Early Eocene Arctic - where winter

82 24-hour darkness restricts the growing season to the summer months - using the Zhang and

83 Wang (2008) index for a region where the summer daily rate of precipitation is equal to 3

$84 \mathrm{~mm} /$ day or more (i.e. 3 warmest months precipitation $>28 \mathrm{~cm}$ ), and the ratio of summer to annual

85 precipitation exceeds 55\%. Huber and Goldner (2012) for their modelling of Eocene

86 precipitation regimes used a simplification of the Zhang and Wang (2008) index, defining

87 monsoonal climates as being highly seasonal precipitation regimes where summer wet season

88 precipitation was $>70 \%$ of the annual total. In the Eocene Arctic, West et al. (2015) proposed

89 that the summer light season precipitation = Growing Season Precipitation (GSP), allowing

discrimination of monsoonal or non-monsoonal conditions using CLAMP. At McAbee's

91 paleolatitude the light regime poses no restriction on plant growth. As we cannot discriminate

92 between a summer or winter wet season using CLAMP, we seek to reject a null hypothesis of

93 monsoonality (i.e., highly seasonal precipitation) using a modification of the simpler definition

94 of Huber and Goldner (2012) for monsoonal climates as being highly seasonal precipitation

95 regimes where wet season precipitation $>70 \%$ of the annual total.

Two historically and independently collected fossil leaf collections from the McAbee site

97 (Figures 1 and 2; coordinates $50^{\circ} 47.831^{\prime} \mathrm{N}, 1^{\circ} 1^{\circ} 08.481^{\prime} \mathrm{W}, 586 \mathrm{~m}$ elevation, using a

98 Garmin ${ }^{\mathrm{TM}}$ GPS, July 30, 2015) were examined for this study. The University of Saskatchewan

99 (US) collection was made by J.F. Basinger in the late 1980s, and was used for initial leaf

100 physiognomic estimates of climate for McAbee (e.g., Greenwood and Wing 1995; Greenwood et

101 al. 2005; Smith et al. 2010, 2012). The Brandon University (BU) collection was made by S.B.

102 Archibald in the early 2000s. Neither collection was made within a site stratigraphy (J.F.

103 Basinger and S.B. Archibald, pers. comm., Sept. 4, 2015). The McAbee main site (Fig. 2) is an 
104 approximately $0.5 \mathrm{~km}$ stretch of lacustrine shale interbedded with volcanic ash and tephra 105 referred to as the McAbee beds, an unnamed unit within the Tranquille Formation of the 106 Kamloops Group (Ewing 1981; Read and Hebda 2009; Hebda 2012). Volcanic rocks from the 107 Dewdrop Formation, the upper-most unit within the Kamloops Group, overlie the McAbee beds 108 in outcrop (Fig. 2). Radiometric dating on volcanic ash layers within the McAbee beds using the $109{ }^{40} \mathrm{Ar}-{ }^{39} \mathrm{Ar}$ method estimated the age of the McAbee fossil beds at $52.9 \pm 0.83 \mathrm{Ma}$ (Archibald et 110 al. 2010), thus representing environments just prior to the EECO (50-52 Ma; Zachos et al. 2008).

111 The fossil bearing sediments from this site represent a local near-shore environment (Read and 112 Hebda 2009), thus the fossil megaflora represent a lake-shore forest flora due to specific 113 transport and taphonomic properties of leaves (Greenwood 1992; Burnham 1994; Steart et al. 114 2002).

116 1977; Manchester 1991) were sampled from a limited area of outcrop encompassing where the

117 University of Saskatchewan collection was made (Fig. 2, 'US'), and from an outcrop of the 118 McAbee beds $4 \mathrm{~km}$ west (Wilson 2008). These earlier collections were made from a series of 119 small benches cut into the strata in situ, or were recovered from scree float derived from these 120 exposures (J.F. Basinger and S.B. Archibald, pers. comm., Sept. 4, 2015). In the late 1990s a 121 road was bulldozed at the base of the fossil-bearing sediments (Wilson 2008; Read and Hebda 122 2009; Hebda 2012). Subsequent to the road construction, collecting and description of fossil 123 plants was from outcrop exposed in the cut faces above the road bed (e.g., Dillhoff et al. 2005).

124 All of these collections treated the McAbee beds as a single assemblage (the 'McAbee beds 125 flora'), not accounting for any differences in taxonomic composition or relative abundance of 126 taxa between subsequent levels within the site stratigraphy $(1-10 \mathrm{~m})$ or lateral variation over 0.5 
$127 \mathrm{~km}$ within the beds (Read and Hebda 2009). Work at the Early Eocene Falkland Okanagan

128 Highlands site (Fig. 1), in similar lithologies to the McAbee beds, has demonstrated significant

129 differences in taxonomic composition and also leaf physiognomy over a stratigraphic depth of

1302.9 m, likely reflecting 6000-8000 years of lake sedimentation and climate change (Smith et al.

131 2009, 2012). Recent survey work has shown considerable differences in plant taxon dominance

132 and presence-absence between stratigraphic levels and laterally within the McAbee beds (Read

133 and Hebda 2009; Hebda 2012 see Fig. 2 (A \& B) and Table 1 herein), matching in part the

134 Falkland observations. It is not known, however, whether the leaf assemblage physiognomy -

135 such as mean leaf size, a key character for estimating precipitation - varies between stratigraphic

136 levels at McAbee.

Parauthochthonous leaf assemblages - assemblages of leaves transported short distances

138 down-stream or laterally within a lake - show a smaller mean leaf size than an authochthonous

139 assemblage - those directly deposited beneath the trees such as near shore lake - due to

140 preferential loss with transport of larger leaf size classes within and between leaf taxa (Roth and

141 Dilcher 1978; Greenwoood 1992, 2007; Steart et al. 2002). These same patterns have been seen

142 in Eocene lake sediment leaf assemblages over short stratigraphic distances of $<5 \mathrm{~m}$ (e.g.,

143 Greenwood 1991; Smith et al. 2009, 2012). At Falkland, Smith (2011; Smith et al. 2009, 2012)

144 summed leaves from short stratigraphic spans, but recognized three separate units based on

145 volcanic tuff marker beds and lithological breaks. However, as the lithologies in the three

146 Falkland units were similar (and therefore the energy of deposition is comparable), changes in

147 mean leaf size in the Falkland deposit between the three units were interpreted as being caused

148 by changes in annual precipitation amounts over time (Smith et al. 2009, 2012). If similar

149 differences between samples exist in the McAbee flora as were recorded for Falkland, combining 
150 the historical McAbee collections may mask differences in mean leaf size, and therefore

151 precipitation changes over the time interval between samples. This point is assessed here by

152 comparing the mean leaf sizes of the US and BU collections.

The climate of McAbee has been previously studied using both fossil data and computer

154 models resulting in: MAT estimates of $9.5^{\circ} \mathrm{C}$ (Dillhoff et al. 2005), $10.1^{\circ} \mathrm{C}$ (Smith et al. 2010),

155 and $12.8^{\circ} \mathrm{C}$ (Huber and Caballero 2011); MAP estimates ranging from $99 \mathrm{~cm} \cdot \mathrm{a}^{-1}$ (Smith et al.

156 2010) to $121 \mathrm{~cm} \cdot \mathrm{a}^{-1}$ (Dilhoff et al. 2005); and CMMT estimates ranging from $-2{ }^{\circ} \mathrm{C}$ (Dilhoff et

157 al. 2005) to $8{ }^{\circ} \mathrm{C}$ (Archibald et al. 2014), with a median estimate of $5.2{ }^{\circ} \mathrm{C}$ (Huber and Caballero

158 2011). In addition, the world climate regime model by Huber and Goldner (2012) places this area

159 in an ever-wet climate, but this has not been demonstrated by direct analysis of paleontological

160 climate proxies such as those provided by plant fossils.

The aims of this study therefore are: (1) to determine if the existing historical Brandon

162 University and University of Saskatchewan collections statistically represent a similar leaf

163 population (as measured by mean leaf size) in order to combine them for climatic analysis; (2) to

164 determine if a combined collection yields more precise climatic estimates; (3) and to reconstruct

165 the paleoclimate and precipitation seasonality of the McAbee megaflora to determine if this

166 region of the Okanagan Highlands experienced a highly seasonal precipitation (i.e., 'monsoonal'),

167 or 'ever-wet' climate regime.

168 Materials and Methods

169 Fossil Flora

170 The first of the two fossil samples examined in this study was collected by S.B.

171 Archibald in the early 2000s and is currently curated at Brandon University (BU). This collection 
172 consists of 143 specimens - none of which have been used in previous climatic studies. The

173 second collection was made by J.F. Basinger in the 1980s, and was previously curated at the

174 University of Saskatchewan (US). Part of this collection (49/124 specimens) was loaned to

175 Brandon University for this study and had been previously analysed for paleoclimate by

176 Greenwood and Wing (1995), Greenwood et al. (2005), Smith et al. (2010, 2012), and also

177 reported for leaf size analysis in Dillhoff et al. (2013). The prior paleoclimate and taxonomic 178 analyses by Dillhoff et al. (2005) of the McAbee flora were based on leaves collected from 179 multiple quarries (Fig. 2) and housed in the Thompson Rivers University collection. The two 180 collections used in this study were excavated at single quarries but were at different stratigraphic 181 levels and/or laterally separated from each other within the McAbee site (Figs. 2 \& 3). This 182 required the collections to be analyzed to show if they represent statistically similar leaf 183 populations. The TRU collection was not available for analysis.

\section{Leaf Morphotyping}

The fossil leaves of both the BU and US collections were separated into distinctive morphotypes (Figs. 4 \& 5) based on leaf characters defined in the Manual of Leaf Architecture

187 (MLA; Ellis et al. 2009). The morphotype process serves to organize a fossil flora into distinct categories, which act as an approximation of a biological species, and as such does not require an

189 in depth taxonomic analysis of the fossil flora (Ellis et al. 2009; Yang et al. 2011, 2015). Important morphological characteristics considered in this process include: leaf size, margin

191 type, apex shape, base shape, and venation. Each morphotype is defined using the character 192 scores of multiple leaves representative of the morphotype, entered into the MLA pro forma. 193 Scores of leaf size class for each leaf morphotype were made using both the leaf size classes 194 from the MLA (Ellis et al. 2009) and those used in CLAMP (Yang et al. 2011, 2015). 
195 Photographs of examples of these morphotypes were taken using a Nikon D3200 DSLR 24

196 megapixel digital camera with a Nikon 55-200 mm DX VR lens and were slightly modified to

197 remove lens geometric aberration, and to optimize contrast and brightness using the image

198 editing feature of the camera.

199 Statistical Analyses

200 Statistical analyses were performed on the two collections in order to determine if they

201 represent statistically similar or different leaf populations so that they may be combined during

202 climatic analysis. To test this, the average area in $\mathrm{mm}^{2}$ of each leaf morphotype from both

203 collections was directly measured using the equation:

204 (1) Leaf Area $=$ Length $\times$ Width $\times 0.67$ (Cain and Castro 1957; Greenwood 1992).

The leaf area data was analyzed using two one-way ANOVA tests in Microsoft $®-E x c e l$

206 2007's data analysis function. The first ANOVA test included all specimens in both collections

207 in order to determine the base statistical difference of the two collections. The second ANOVA

208 excluded all fossils that were deemed incomplete (broken specimens or those missing features)

209 in order to remove any statistical imprecision which would have occurred in measuring

210 incomplete specimens.

\section{Leaf Margin Analysis (LMA)}

A strong correlation has been repeatedly observed between the percentage of woody dicot

213 species with toothed or untoothed leaf margins and MAT (Bailey and Sinnott 1916; Wolfe 1979;

214 Wilf 1997; Greenwood et al. 2004; Peppe et al. 2011). To conduct the Leaf Margin Analysis

215 (LMA) the morphotypes were scored using a binomial scale of non-toothed vs. toothed 
216 consistent with the recommendation of Wilf (1997). The LMA equation (2) of Wing \&

217 Greenwood (1993) was applied, where LMP is the percent of non-toothed leaves in a flora. The

218 global LMA equation (3) of Peppe et al. (2011) was also applied in our analysis, and is derived

219 from a global set of 92 sites that represent more diverse vegetated environments than used to

220 derive the original LMA equation, but has a much greater standard error (Peppe et al. 2011). This

221 is intended to counteract the regional variances that have been observed between MAT and the

222 proportion of untoothed leaves found in a flora (Gregory-Wodzicki 2000; Greenwood et al.

223 2004; Royer et al. 2012).

224 (2) $\mathrm{MAT}=1.141+(30.6 \times L M P)$

225 (3) $\mathrm{MAT}=4.60+(20.4 \times L M P)$

226 Leaf Area Analysis (LAA)

For LAA, each morphotype was measured indirectly using the Raunkiaer-Webb size

228 class templates provided by the Manual of Leaf Architecture (Ellis et al. 2009) and then analyzed

229 to generate an estimate for MAP. In addition, the smallest and largest specimens from each

230 morphotype were directly measured using equation (1), averaged, and analyzed to estimate

231 MAP. In morphotypes where there was only one fossil, that measurement was used as the

232 average area of the morphotype. Morphotypes containing damaged or incomplete fossils that

233 could not be directly measured were excluded from the analysis, although future work will

234 incorporate these fragmentary specimens into the analysis using the leaf vein density scaling

235 method (Sack et al. 2012; Merkhofer et al. 2015).

236 In LAA, each measurement of leaf area size, both indirect and direct yielded a specific

237 natural log value that was used to calculate the mean area of each morphotype. These natural log 
238

239

240

241

242

243

244

245

246

247

248

249

250

251

252

253

254

255

256

257

258

259

averages were then used to find the mean natural log of leaf area size (MLnA) of each collection, which were used to estimate MAP. Equation (4) (Wilf et al. 1998), was used on the direct and indirect measurements from both the BU and combined collections to estimate the MAP. In addition, we applied the global LAA equation (5) from Peppe et al. (2011), to the set of direct measurements although this equation has lower precision due to a large standard error.

(4) $\ln (\mathrm{MAP})=0.548 \times M \ln A+0.768$

(5) $\ln (\mathrm{MAP})=0.283 \times M \ln A+2.92$

\section{CLAMP (Climate Leaf Analysis Multivariate Program)}

Similar to LMA and LAA the Climate Leaf Analysis Multivariate Program (CLAMP) utilizes the evolutionary adaptations of leaves to their respective environments. This relationship has been observed and quantified in a dataset of leaf characteristics from floras around the world (Wolfe 1995; Spicer et al. 2004). CLAMP has been further refined through the use of globally gridded climate data (New et al. 2002; Spicer et al. 2009), which through the use of canonical correspondence analysis (Wolfe et al. 1997) allows for a best fit of the fossil physiognomy onto the physiognomy of modern floras in a 3-dimensional plot of 31 leaf characteristics. Since CLAMP is based on multiple leaf characters and their correlation with modern climates, it generates data on precipitation seasonality and growing season which LMA and LAA cannot provide (Yang et al. 2011, 2015). Fossils were scored and analyzed based on guidelines from CLAMP Online (Yang et al. 2011; http://clamp.ibcas.ac.cn).

The fossil floras were initially analyzed using the PhysgGlobal378 data set, which includes 378 modern vegetation sites from around the world (e.g., North America, Japan, East Asia, Southern Africa, Southern Asia, India, New Zealand, and Australia) (Yang et al. 2015). 
260 The large increase in climates represented in the PhysgGlobal378 data set results in a decrease in 261 the precision of the climate predictions (Yang et al. 2015). However, the utility of this data set 262 lays in indicating which subset of the CLAMP data sets should be used for analysis (Yang et al. 263 2015). Results from the analysis using the PhysgGlobal378 data indicated that the McAbee fossil 264 was distant in physiognomic space from the monsoonal South Asian and Indian vegetation. The 265 Physg3brcAZ_GRIDMet3brAZ dataset consists of 144 modern sites that are primarily from 266 temperate Northern Hemisphere localities (e.g., North America, Japan) but excludes cold 267 temperature sites (Yang et al. 2011). This dataset was selected for the primary analysis of the 268 McAbee fossil flora as it is based on vegetated sites from non-monsoonal climates; the climate 269 regime previously modelled for this region (Huber and Goldner 2012). The climate data 270 generated from CLAMP include temperature estimates (MAT, Warm Month Mean Temperature 271 (WMMT), CMMT), precipitation estimates (Growing Season Precipitation, Mean Month 272 Growing Precipitation, amount of precipitation in the three wettest months and three driest 273 months) and other climate data (Growing Season Length, Relative Humidity, and Specific 274 Humidity)

275 Results

276 Leaf Morphotyping

After scoring the leaf architectural features of a total of 192 fossil leaves, 43 distinct

278 morphotypes were defined using the character set and pro forma of Ellis et al. (2009). Of these, 27929 were unique to the BU collection, 3 were unique to the US collection, and 11 were present in 280 both collections $\left(\right.$ Table $1^{\mathrm{c}}$ ). These data show different taxonomic assemblages between these two

\footnotetext{
${ }^{\mathrm{c}}$ Tables S1 \& S2, online supplementary materials
} 
281 collections is typical of the differences observed between quarry sites in the McAbee beds (Read

282

283

284

285

286

287

288

289

290

291

292

293

294

295

296

297

298

299

300

301

302

and Hebda 2009; Hebda 2012). Photographs of specific morphotypes are presented in Figures 4 and 5. Several morphotypes were identified: Sassafras hesperia (Fig. 4A \& B); both collections), Acer (Fig. 4C; BU), Betula leopoldae (Fig. 4D; BU), Fagus langevinii (Fig. 5A), Comptonia columbiana (Fig. 5C \& F; BU), and Ulmus (Fig. 5I; both collections). Fagus langevinii (Fig. 5A), was found to be the most common morphotype in both collections with 17 of 143 specimens in the BU collection and 14 of 49 specimens in the US collection. Other leaf morphotypes were only tentatively identified: Cercidiphyllum / Joffrea (not illustrated), cf. Vitis (Fig. 4E), cf. Crataegus (Fig. 4F), cf. Bignoniaceae (Fig. 4G, likely also present as seeds), cf. Decodon (Fig. 4H), cf. Neviusia (not illustrated), cf. Tetracentron (not illustrated), cf. Fraxinus (Fig. 5B), and cf. Platanaceae (Fig. 5G).

\section{Statistical Analyses}

The numerical values for the ANOVA tests are as follows: ANOVA test 1 statistical value 1.95, critical value 4.03; ANOVA test 2 statistical value 2.26, critical value 4.13. Both statistical tests found that the BU collection and US collection were not statistically different in terms of leaf area. Details of the tests can be found in Tables 2 and 3. This allows for the combination of the two collections into the larger combined collection. Subsequent climatic tests (LMA and LAA) showed that the BU collection agreed with the originally published US collection (Greenwood and Wing 1995) showing the two collections likely experienced similar climates despite being separated by an unknown length of time. This stability of climate through time also allows for the blending of the two collections in the combined collection. Furthermore, when plotted in physiognomic space by CLAMP, the BU collection and combined collection 
303 occur very near to each other (Fig. 6) showing that the two collections have near identical

304 physiognomies and that the creation of the combined collection was justified.

\section{$305 \quad$ Leaf Margin Analysis}

In the BU collection 23\% (9/40) of all morphotypes were found to be non-toothed while

$30726 \%$ (11/43 morphotypes) of the combined collection was found to be non-toothed ${ }^{\mathrm{d}}$. The

308 estimate for MAT for the BU collection using equation (2) was $8.2 \pm 2.0{ }^{\circ} \mathrm{C}$ and $9.3 \pm 4.8{ }^{\circ} \mathrm{C}$

309 using equation (3). The combined collection yielded the results of $9.2 \pm 2.0^{\circ} \mathrm{C}$ using equation (2)

310 and $9.9 \pm 4.8^{\circ} \mathrm{C}$ using equation (3) (Table 4).

\section{Leaf Area Analysis}

The MLnA values for both the BU and combined collections were 7.3 and 7.1 when

313 using the indirect and direct measurements respectively ${ }^{\mathrm{e}}$. These values are similar to the MLnA

314 values found for the US collection, which were 7.2 and 6.9 in this study and reported to be 7.0

315 (direct measurement of US collection) in Dillhoff et al. (2013). Table 4 shows the MAP

316 estimates for the BU and combined collection using equation (4) on both the indirect and direct

317 measurements and equation (5) on the direct measurements. A wet climate $\left(>100 \mathrm{~cm} \cdot \mathrm{a}^{-1}\right)$ is

318 suggested by all the estimates, but the indirect measurements yielded higher estimates than the

319 direct measurements when using equation (4). Estimates using equation (5) were highest of all

$320\left(>130 \mathrm{~cm} \cdot \mathrm{a}^{-1}\right)$ but had large errors (Table 4). The differing number of morphotypes in each

321 collection likely caused the small difference in the MAP estimate between the BU and combined

322 collections.

\footnotetext{
${ }^{\mathrm{d}}$ Tables S3 \& S4, online supplementary materials.

e Tables S5 \& S6, online supplementary materials.
} 


\section{CLAMP (Climate Leaf Analysis Multivariate Program)}

The completeness statistics for BU and the combined collections were high $(0.807$ / 81\%

325

326

327

328

329

330

Figure 6 shows the BU and combined collections plotted in multi-dimensional space against modern data points from the CLAMP analysis. This is achieved using canonical correspondence analysis (CCA) which ordinates the data (CCA axes 1 and 2), which shows the environmental vectors (Kovach and Spicer 1996; Spicer 2000; Yang et al. 2011, 2015). The vectors point in the extremity of that specific characteristic, but do not form an average in which the results lie due to the multi-dimensional nature of the analysis. The placement of the BU and combined collection in physiognomic space shows that both collections experienced wet, but non-monsoonal conditions as the three dry months (THREE_DRY), the three wet months (THREE_WET), and mean growing season precipitation per month (MMGSP) vectors all point in the same direction which indicates no major seasonal change in precipitation. This assessment is supported by numerical estimates of the three driest months data generated by CLAMP (Table 5) which shows that; (1) the three driest months received $\sim 30 \mathrm{~cm}$, or approximately one quarter

\footnotetext{
f online supplementary materials.
} 
345 of the total estimated precipitation; (2) the three wettest months' received $\sim 60 \mathrm{~cm}$, only twice the 346 amount of the three driest months; and (3) MAP $>100 \mathrm{~cm} \cdot \mathrm{a}^{-1}$ (Table 5). These data indicate that 347 there was slight seasonality in terms of precipitation but no markedly wet or dry seasons. Thus, 348 conditions at McAbee during the Early Eocene were not highly seasonal under the definition 349 applied (THREE_WET $>70 \%$ of MAP), and thus not monsoonal.

\section{Discussion}

\section{McAbee Climate Interpretations}

Precipitation seasonality is a climatic feature that is often overlooked in paleoclimatic reconstructions, but is essential to understanding ancient environments and ecosystems (Huber and Golder 2012; Eldrett et al. 2014; West et al. 2015). Huber and Goldner (2012) modeled Early Eocene climate and mapped climate regimes across the Eocene globe, and were able to highlight two major precipitation patterns: ever-wet and monsoonal (i.e., as defined by Huber and Goldner (2012) for their model as the ratio of summer to annual precipitation $>70 \%$ :). Seasonality, however, is not limited to variable precipitation patterns, but may also be the result of seasonal changes in temperature (e.g., this study) or light regime (e.g., West et al. 2015). collection agree with each other, the MAT result from Greenwood and Wing (1995), and the results from using equation (3) (Table 4). The indirect and direct methods of measuring leaves

363 for LAA yielded different results for annual precipitation (MAP) for the BU and combined 364 collections, but are concordant due to the method's large error estimates. They also agree with results from the US collection (Greenwood and Wing 1995; Table 4). The difference between the

366 direct and indirect measurement estimates of MAP is caused by the direct method's inability to 
367 utilize damaged specimens. Several morphotypes (17/40- BU collection; 14/43- combined

368 collection) from each collection were not analyzed using direct measurements for this reason. In

369 addition, taphonomic bias affects LAA estimates as smaller leaves are more likely to be

370 preserved (Greenwood 1991, 1992; Steart et al. 2002) which suggests that the upward error

371 values of LAA estimates are more likely to reflect the actual climate as smaller leaves indicate a

372 drier climate. Vein density scales with leaf size offering a solution to the problem of fragmented

373 leaves (Sack et al. 2012; Merkhofer et al. 2015), and future work will apply this approach to the

374 McAbee flora.

The results from the CLAMP analysis indicate a warm $\left(\mathrm{MAT} \sim 13{ }^{\circ} \mathrm{C}\right)$, mild $(\mathrm{CMMT} \sim 5$

$\left.376{ }^{\circ} \mathrm{C}\right)$, and wet (GSP $\sim 130 \mathrm{~cm}$ ) climate for both the BU and combined collections. Differences in

377 the estimates between the methods are because CLAMP uses 31 leaf characters for analysis

378 (Wolfe 1993; Spicer 2000; Yang et al. 2011, 2015). The MAT and CMMT results generated by

379 CLAMP are mostly consistent with other published results for Okanagan Highlands sites

380 (Archibald and Mathewes 2000; Archibald et al. 2005; Greenwood et al. 2005; Smith et al. 2009, 381 2012; Dillhoff et al. 2013; Mathewes et al. this volume). The one exception is the CMMT

382 estimate of $-2{ }^{\circ} \mathrm{C}$ by Dillhoff et al. (2005) from CLAMP, which based on the presence of both 383 palm pollen and bruchine beetles, would appear an underestimate. These and other data from 384 plant and insect fossils from other Okanagan Highlands sites suggest McAbee winters would 385 likely have been mild and frost-free for much of the season (Greenwood et al. 2005; Smith et al. 386 2012; Archibald et al. 2014; Mathewes et al. this volume; Moss et al. this volume). Archibald et al. (2014) identified palm-seed feeding bruchine beetles at McAbee,

388 'constraining CMMT to $>8{ }^{\circ} \mathrm{C}^{\prime}$ on the basis of the higher temperatures at which palms experience 389 lethal freezing damage under Eocene high $\mathrm{pCO}_{2}$, citing experimental trials with the cold tolerant 
390 palms Chamaerops humilis and Trachycarpus fortunei by Royer et al. (2002). However: (1)

391 Royer et al. (2002, p. 965) recommended an adjustment of 'at least +1.5 to $+3{ }^{\circ} \mathrm{C}^{\prime}$ to the plant 392 NLR derived CMMT (palms in this case), not 'CMMT $>8{ }^{\circ} \mathrm{C}$ ', which represents the upper limit 393 of adjustment assuming a minimum CMMT for palms of $5{ }^{\circ} \mathrm{C}$ (Greenwood and Wing 1995); and 394 (2) based on more precise analyses of the modern distribution limits of palms, the lower limit for 395 CMMT for palms has been calculated as $<5{ }^{\circ} \mathrm{C}$ (Walther et al. 2007 for Trachycarpus fortunei; 396 Fang et al. 2011 for 7 species of Chinese palms ${ }^{\mathrm{g}}$; Archibald et al. 2014 for Washingtonia 397 filifera). According to data listed by Fang et al. (2011; summarised in Table S7) some palms may 398 naturally grow where CMMT is as low as $1.3^{\circ} \mathrm{C}$, with these authors listing the lower limit of 399 CMMT for $T$. fortunei as $-3.2^{\circ} \mathrm{C}$. This much lower CMMT for $T$. fortunei seems out of step with 400 all other temperature limit data for palms, and so we accept the higher CMMT value of $2.2{ }^{\circ} \mathrm{C}$ 401 for this species from Walther et al. (2007). Allowing for the revised lower CMMT's provided for 402 palms as noted here, the $\mathrm{pCO}_{2}>800$ ppm adjusted CMMT for palms (i.e., Royer et al. 2002) is 403 conservatively in the range $4.3{ }^{\circ} \mathrm{C}(1.3$ from Fang et al. $2011+3.0)$ to $5.2{ }^{\circ} \mathrm{C}(2.2$ from Walther 404 et al. $2002+3.0$ ). In our view, constraining McAbee CMMT to $>8{ }^{\circ} \mathrm{C}$ is not appropriate as our 405 estimate of $5.1 \pm 3.4{ }^{\circ} \mathrm{C}$ from CLAMP overlaps within its errors with the revised palm CMMT 406 lower limit, with the presence of palms indicating CMMT range of $4.3-8.5^{\circ} \mathrm{C}$. Combining the 407 temperature results from the physiognomic analyses (LMA, LAA, and CLAMP) provides a 408 MAT range of $\sim 8-13^{\circ} \mathrm{C}$, a WMMT of $\sim 21^{\circ} \mathrm{C}$, and a CMMT of $\sim 5^{\circ} \mathrm{C}$. 410 values are considered and the results are not statistically different (Table 4). The MAP estimates 411 are similar in value with the GSP estimates generated by CLAMP; the estimated $\sim 8$ month

g Table S7, online supplementary materials. 
412 growing season (Table 5) may also represent the time period being captured for both MAP and

413 GSP. Both methods suggest a wet $\left(\right.$ MAP $\left.>100 \mathrm{~cm} \cdot \mathrm{a}^{-1}\right)$ climate for McAbee. The conditions for a

414 monsoonal climate are not indicated by the results, as defined by Huber and Caballero (2012), as

415 the wettest portion of the year received $\sim 50 \%$ (i.e., $<70 \%$ ) of the total precipitation, i.e. the

416 precipitation was not highly seasonal. Non-monsoonal conditions are further indicated by

417 canonical correspondence analysis (Fig. 6) and the (THREE_DRY) three driest months' estimate

418 (Table 5). This interpretation agrees with the global climate model by Huber and Goldner (2012),

419 which placed the Okanagan Highlands sites in an ever-wet, not monsoonal condition.

420 Precipitation estimates of $\sim 30 \mathrm{~cm}$ in the three driest months and $\sim 60 \mathrm{~cm}$ of precipitation in the

421 three wettest months shows some precipitation seasonality, but does not resolve the time of year

422 that was the 'dry season'. These data (Table 5) would suggest a climate similar to the modern day

423 North Pacific coast of North America (e.g., Vancouver BC (from Environment Canada,

424 http://climate.weather.gc.ca/climate_normals/index_e.html), MAT $9.9{ }^{\circ} \mathrm{C}, \mathrm{CMMT} 3{ }^{\circ} \mathrm{C}$, WMMT

$42517.4^{\circ} \mathrm{C}$, MAP $117 \mathrm{~cm} \cdot \mathrm{a}^{-1}$, THREE_WET $50 \mathrm{~cm}$, THREE_DRY $12 \mathrm{~cm}$; Portland OR (from

426 NOAA, http://www.ncdc.noaa.gov/cdo-web/datatools/normals), MAT $12.0{ }^{\circ} \mathrm{C}, \mathrm{CMMT} 4.2{ }^{\circ} \mathrm{C}$,

427 WMMT $20.3^{\circ} \mathrm{C}$, MAP $92.2 \mathrm{~cm} . \mathrm{a}^{-1}$, THREE_WET $42.8 \mathrm{~cm}$, THREE_DRY $8.2 \mathrm{~cm}$ ), but with

428 wetter dry seasons than the modern sites. The megaflora of the McAbee collections indicates

429 some level of temperature seasonality as they contain deciduous trees such as Fagus, and fossil

430 leaves found in mats on the exposed shale surfaces are consistent with seasonal leaf-fall. Cool

431 average winter temperatures and a non-permanent growing season (Table 5) show that the

432 McAbee EECO forest was seasonal with respect to temperature, and that precipitation was also

433 seasonal with a wet and a dry season (THREE_WET $\sim 60 \mathrm{~cm}$ vs. THREE_DRY $30 \mathrm{~cm}$ ).

\section{Fossil Floras \& Census Collection}



time of rapid evolution and the early radiation of many dicot families (DeVore et al. 2005). The

437 fine scale preservation of lake sediments of these localities may allow these diversification 438 events to be studied in great detail during the warmest part of the Cenozoic. An unbiased census 439 approach for fossil collecting is critical for observing and identifying these fine-scale patterns or 440 trends in diversity of fossil plant communities and the reconstruction of fossil climates 441 (Greenwood 1991; Greenwood and Basinger 1993; Wilf et al. 2003, 2005; Iglesias et al. 2007;

442 Smith et al. 2009).

The McAbee collections have been traditionally treated as a single assemblage (the 'McAbee beds flora'), not accounting for any differences in taxonomic composition or relative abundance of taxa between subsequent levels within the McAbee site stratigraphy or lateral 446 variation over $0.5 \mathrm{~km}$ within the beds (Read and Hebda 2009). This, however, can limit the use 447 of the flora for observing fine scale patterns and trends in regional diversity that may be 448 preserved in the geological record. Previous work conducted at the EECO Falkland OH site has 449 demonstrated significant differences in taxonomic composition and leaf physiognomy, and 450 therefore climate, over a stratigraphic depth of $2.9 \mathrm{~m}$ (Smith et al. 2009, 2012). Based on 451 sedimentation rates at the Horsefly BC site (0.36-0.47 m per 1000 years; Wilson and Bogen 452 1994; Barton 1998), Smith et al. (2012) calculated that the $\sim 3$ m they sampled for megaflora 453 represented $\sim 6000-8000$ years of lake history. 
458 that the average area of leaves was similar over distance and through time, suggesting a stable

459 climate regime. The size of the collections poses a problem when interpreting diversity and

460 species composition of the McAbee flora. The different morphotypes unique to each collection

461 (Table 1), however seems to suggest that diversity and species composition of the lake-side

462 forest may have been changing regionally over time. Although, local leaf physiognomy may

463 have been constrained to specific architectural elements correlated to regional climate. These

464 observations reinforce the need for census style collection methods for fossil floras, including

465 McAbee.

466 The combined collection and McAbee climate stability

467

468

469

470

471

472 contrasts with Smith et al.'s (2009) observed pattern for the nearby Falkland site. The apparent

473 stability of climate for the McAbee site requires more study, both to confirm the pattern and to

474 ascertain its cause. For this present study, however, only a portion of the US collection (49/124

475 specimens) was available for climatic analysis. Analysis of this small collection generated

476 erroneous results that did not agree with the previously published data or the results from the BU

477 collection. This is likely a result due to a small number of morphotypes in this partial collection

478 (14) compared to the previous study (24; Greenwood and Wing 1995). In order to minimize

479 uncertainties and potential errors, it is recommended that at least 20 morphotypes be available

480 for an adequate climate reconstruction (Wolfe 1993; Spicer et al. 2005; Yang et al. 2011). 
482 techniques utilized. The BU collection was collected over several weeks with the majority of

483 found specimens collected. The US collection; however, was made over the span of a few days

484 with "high quality" specimens being preferentially collected. Neither collection, however, was

485 census sampled. As the BU collection represents the majority of flora found, the results are likely

486 more representative of the actual McAbee EECO flora and therefore climate, even if this

487 collection is not a true census sample.

Despite the success in this study, census sampling is still preferred method for fossil leaf

489 collection for future climatic analyses based on leaf physiognomy, as a short sequence of strata

490 may contain a rapidly changing flora with leaf size differing between successive layers in

491 response to regional shifts in precipitation or taphonomic effects (Greenwood 1991; Smith et al.

492 2009, 2012). Census sampling has been applied to other North and South American fossil floras

493 (see Greenwood and Basinger 1993; Wilf et al. 2003, 2005; Iglesias et al. 2007; Smith et al.

4942009,2012 ), and the further application of this collection method to the Okanagan Highlands

495 floras will allow further testing and comparison to these Eocene fossil floras found across the

496 Americas.

497 Conclusions

The two fossil collections (BU and US), are not statistically different in terms of leaf area,

499 which allowed them to be combined for additional climate analysis. The statistical similarities

500 and agreement between MAT and MAP estimates of the BU and total US collection suggests

501 that the environment of McAbee was relatively stable over this time with respect to precipitation

502 despite there being distinct taxonomic changes between the collections. The combined collection 
503 likely yielded more precise climatic estimates compared to the BU collection due to the greater

504 number of morphotypes included in its climatic analysis, but the BU collection represents a more

505 constrained view of the climate as opposed to the time averaged combined collection. This

506 method of combining collections that are separated in time, however, cannot be utilized in all

507 cases due to the possibility of taxonomic or climatic changes occurring through a relatively small

508 amount of deposition. Census collecting should be used to gain the most precise and time

509 constrained climatic estimates in the future.

Leaf physiognomic analysis using LMA, LAA, and CLAMP show that the climate of

511 McAbee during the EECO was microthermal (MAT $\sim 8-13{ }^{\circ} \mathrm{C}$, WMMT $\sim 21{ }^{\circ} \mathrm{C}$ ) with mild

512 winters $\left(\mathrm{CMMT} \sim 5^{\circ} \mathrm{C}\right.$ ) and high levels of precipitation (MAP 100-130 cm. $\mathrm{a}^{-1}$ ). In terms of

513 seasonality, precipitation was relatively constant year-round with the driest portion of the year

514 receiving approximately $50 \%$ of the amount of precipitation as the wettest. There is no evidence

515 to suggest there were monsoonal or highly seasonal precipitation during this time. Therefore our

516 data agree with the climatic modelling by Huber and Goldner (2012) that the interior area of

517 British Columbia experienced an ever-wet climate regime during the Early Eocene.

\section{Acknowledgements}

519 We thank Bruce Archibald and Jim Basinger for the loan of their McAbee collections, and for

520 assistance with field work. D.R.G. acknowledges the support from a discovery grant from the

521 Natural Sciences and Engineering Research Council of Canada (DG-311934) and a Committee

522 for Research and Exploration grant from the National Geographic Society (9652-15). C.K.W.

523 acknowledges financial support from the University of Saskatchewan. C.A.C.G. gives additional

524 thanks to Pamela Rutherford of Brandon University for assistance in statistical analysis and Bob 
525 Spicer (Open University) for assistance with the CLAMP analysis set-up. Special thanks to

526 Markus Sudermann for taking the leaf morphotype images presented in this paper, and for field

527 assistance to D.R.G. and C.K.W. at the McAbee fossil beds in 2015. This work was completed as

528 part of an undergraduate thesis by C.A.C.G. Constructive and thoughtful reviews by Dana Royer 529 and Dan Peppe led to important improvements to the paper.

\section{References}

Archibald, S.B., and Farrell, B.D. 2003. Wheeler's dilemma. Acta Zoologica Crakoviensia, 46: 17-23.

Archibald, S.B., and Mathewes, R.W. 2000. Early Eocene insects from Quilchena, British Columbia, and their paleoclimatic implications. Canadian Journal of Zoology, 78: 14411462.

Archibald, S.B., Bossert, W.H., Greenwood, D.R., and Farrell, B.D. 2010. Seasonality, the latitudinal gradient of diversity, and Eocene insects. Paleobiology, 36(3): 374-398. doi: $10.1666 / 09021.1$

Archibald, S.B., Greenwood, D.R., Smith, R.Y., Mathewes, R.W., and Basinger, J.F. 2011. Great Canadian Lagerstätten 1. Early Eocene Lagerstätten of the Okanagan Highlands (British Columbia and Washington State). Geoscience Canada, 38(4): 155-164.

Archibald, S.B., Morse, G., Greenwood, D.R., and Mathewes, R.W. 2014. Fossil palm beetles refine upland winter temperatures in the Early Eocene Climatic Optimum. Proceedings of the National Academy of Sciences, 111(22): 8095-8100. doi: 10.1073/pnas.1323269111

Bailey, I.W., and Sinnott, E.W. 1916. The climatic distribution of certain types of angiosperm leaves. American journal of botany, 3: 24-39. 
547 Barton, D.G. 1998. Microstratigraphic variation in preservational patterns and meristic counts of

548

549

550

551

552

553

554

555

556

557

558

559

560

561

562

563

564

565

566

567

568

Amyzon aggregatum (Teleostei: Catostomidae) from a 10,000-year interval of the Eocene varved lake deposits of Horsefly, British Columbia. M.Sc. Thesis, The University of Alberta, Edmonton, AB.

Breedlovestrout, R.L., Evraets, B. J., and Parrish, J.T. 2013. New Paleogene climate analysis of western Washington using physiognomic characteristics of fossil leaves. Paleogeography, Palaeoclimatology, Palaeoecology, 392: 22-40.

Burnham, R.J. 1994. Patterns in tropical leaf litter and implications for angiosperm paleobotany. Review of Paleobotany and Palynology, 81: 99-113.

Cain, S.A., and Castro, G.M. 1959. Manual of vegetation analysis. Harper and Brothers Publ. New York.

DeVore, M.L., Pigg, K.B., and Wehr, W.C. 2005. Systematics and phytogeography of selected Eocene Okanagan Highlands plants. Canadian Journal of Earth Sciences, 42(2): 205-214.

Dillhoff, R M., Leopold, E.B., and Manchester, S.R. 2005. The McAbee flora of British Columbia and its relation to the early-middle Eocene 'Okanagan Highlands' flora of the Pacific Northwest. Canadian Journal of Earth Sciences, 42(2): 151-166.

Dillhoff, R.M., Dillhoff, T.A., Greenwood, D.R., DeVore, M.L., and Pigg, K.B. 2013. The Eocene Thomas Ranch flora, Allenby Formation, Princeton, British Columbia, Canada. Botany, 91(8): 514-529. doi: 10.1139/cjb-2012-0313

Eberle, J.J., and Greenwood, D.R. 2012. Life at the top of the greenhouse Eocene world - a review of the Eocene flora and vertebrate fauna from Canada's High Arctic. Geological Society of America Bulletin, 124(1/2): 3-23. doi: 10.1130/B30571.1 
569 Eberle, J.J., Rybczynski, N., and Greenwood, D.R. 2014. Early Eocene mammals from the

570 Driftwood Creek beds, Driftwood Canyon Provincial Park, northern British Columbia.

571 Journal of Vertebrate Paleontology, 34(4): 739-746. doi:

$572 \quad 10.1080 / 02724634.2014 .838175$

573 Eldrett, J. S., Greenwood, D. R., Polling, M., Brinkhuis, H., and Sluijs, A. 2014. A seasonality 574 trigger for carbon injection at the Paleocene-Eocene Thermal Maximum. Climate of the 575 Past, 10(2): 759-769. doi:10.5194/cp-10-759-2014

576 Ellis, B., Daly, D.C., Hickey, L.J., Johnson, K.R., Mitchell, J.D., Wilf, P., Wing, S.L. 2009.

577 Manual of Leaf Architecture. Cornell University Press, Ithaca, N.Y.

578 Ewing, T.E. 1981. Regional stratigraphy and structural setting of the Kamloops Group, south579 580 central British Columbia. Canadian Journal of Earth Sciences, 18(9): 1464-1477.

Fang, J., Wang, Z. and Tang, Z. 2011. Atlas of woody plants in China: distribution and climate. Vol. 1. Springer-Verlag, Heidelberg, Germany.

582 Greenwood, D.R. 1991. The taphonomy of plant macrofossils. In The Processes of Fossilization. 583 Edited by S.K. Donovan. Belhaven Press, London, U.K. pp. 141-169.

584 Greenwood, D.R. 1992. Taphonomic constraints on foliar physiognomic interpretations of Late 585 Cretaceous and Tertiary paleoclimates. Review of Paleobotany and Palynology, 71(1-4): 149-190. doi: 10.1016/0034-6667(92)90161-9

587 Greenwood, D. R. 2007. Fossil angiosperm leaves and climate: from Wolfe and Dilcher to 588 Burnham and Wilf. Courier Forschungsinstitut Senckenberg, 258: 95 - 108. 
589 Greenwood, D.R., and Basinger, J.F. 1993. Stratigraphy and floristics of peat-coal layers of

590

591

592

593

594

595

596

597

598

599

600

601

602

603

604

605

606

607

608

609

Eocene swamp forests from Axel Heiberg Island, Canadian Arctic Archipelago. Canadian Journal of Earth Sciences, 31(9): 1914-1923. doi: 10.1139/e93-169

Greenwood, D.R., and Wing, S.L. 1995. Eocene continental climates and latitudinal temperature gradients. Geology, 23(11): 1044-1048. doi: 10.1130/0091-7613(1995)0232.3.CO;2

Greenwood, D.R., Wilf, P., Wing, S.L., and Christophel, D.C. 2004. Paleotemperature estimation using leaf-margin analysis: Is Australia different? Palaios, 19(2): 129-142. doi: 10.1669/0883-1351(2004)0192.0.CO;2

Greenwood, D.R., Archibald, S.B., Mathewes, R.W., and Moss, P.T. 2005. Fossil biotas from the 'Okanagan Highlands', southern British Columbia and northeastern Washington State: climates and ecosystems across an Eocene landscape. Canadian Journal of Earth Sciences, 42(2): 167-185. doi: 10.1139/E04-100

Greenwood, D.R., Basinger, J.F., and Smith, R.Y. 2010. How wet was the Arctic Eocene rainforest? Estimates of precipitation from Paleogene Arctic macrofloras. Geology, 38(1): 15 - 18. doi: 10.1130/G30218.1

Gregory-Wodzicki, K.M. 2000. Relationships between leaf morphology and climate, Bolivia: implications for estimating paleoclimate from fossil floras. Paleobiology, 26: 668-688.

Hills, L.V. 1965. Palynology and age of early Tertiary basins, interior British Columbia. Ph.D. thesis, University of Alberta, Edmonton, Alberta.

Hebda, R. 2012. Stratigraphy and occurrence of fossils in the main exposure of the McAbee beds and Management Implications: A Preliminary Assessment, October 2012. Prepared for 
610

611

612

613

614

615

616

617

618

619

620

621

622

623

624

625

626

627

628

629

630

Land Tenures Branch, Ministry of Forests, Lands and Natural Resource Operations, B.C., $23 \mathrm{p}$.

Huber, M., and Caballero, R. 2011. The early Eocene equable climate problem revisited. Climate of the Past, 7: 603-633.

Huber, M., and Goldner, A. 2012. Eocene monsoons. Journal of Asian Earth Sciences, 44: 3-23.

Iglesias, A., Wilf, P., Johnson, K.R., Zamuner, A.B., Cúneo, N.R., Matheos, S.D., and Singer, B.S. 2007. A Paleocene lowland macroflora from Patagonia reveals significantly greater richness than North American analogs. Geology, 35: 947-950.

Kovach, W.L., and Spicer, R.A. 1996. Canonical correspondence analysis of leaf physiognomy: A contribution to the development of a new palaeoclimatological tool. Palaeoclimates, 2: $125-138$

Manchester, S.R. 1991. Cruciptera, a new juglandaceous winged fruit from the Eocene and Oligocene of Western North America. Systematic Botany, 16(4): 715-725.

Mathewes, R.W., Greenwood, D.R., and Archibald, S.B. this volume. Paleoenvironment of the Quilchena flora, British Columbia, during the Early Eocene Climatic Optimum. Canadian Journal of Earth Sciences

Merkhofer, L., Wilf, P., Haas, M.T., Kooyman, R.M., Sack, L., Scoffoni, C., \& Cúneo, N.R. 2015. Resolving Australian analogs for an Eocene Patagonian paleorainforest using leaf size and floristics. American Journal of Botany, 102(7): 1160-1173.

Moss, P.T., Greenwood, D.R., and Archibald, S.B. 2005. Regional and local vegetation community dynamics of the Eocene 'Okanagan Highlands' (British Columbia 
Washington State) from palynology. Canadian Journal of Earth Sciences, 42(2): 187204. doi: 10.1139/E04-095

Moss, P.T., Smith, R.Y., and Greenwood, D.R. this volume. A Window into Mid-Latitudinal Early-Eocene Environmental Variability: A high-resolution palynological analysis of the Falkland site, Okanagan Highlands, British Columbia, Canada. Canadian Journal of Earth Sciences

Mustoe, G.E. and Gannaway, W.L. 1997. Paleogeography and paleontology of the Early Tertiary Chuckanut Formation, Northwest Washington. Washington Geology, 25: 3-18.

New, M., Lister, D., Hulme, M., and Makin, I. 2002. A high-resolution data set of surface climate over global land areas. Climate research, 21: 1-25.

Peppe, D.J., Royer, D.L., Cariglino, B., Oliver, S.Y., Newman, S., Leight, E., Enikolopov, G., Fernandez-Burgos, M., Herrera, F., Adams, J.M., Edwin Correa, E., Currano, E.D., Erickson, J.M., Hinojosa, L.F., Hoganson, J.W., Iglesias, A., Jaramillo, C.A., Johnson, K.R., Jordan, G.J., Kraft, N.J.B., Lovelock, E.C., Lusk, C.H., Niinemets, Ü., Peñuelas, J., Rapson, G., Wing, S.L., and Wright, I.J. 2011. Sensitivity of leaf size and shape to climate: global patterns and paleoclimatic applications. New Phytologist, 190: 724-739.

Read, P.B. and Hebda, R., 2009. Geological setting and paleontology of the fossiliferous Eocene beds near McAbee, southwestern British Columbia. Report to the Ministry of Agriculture and Lands, British Columbia, Contract CCLAL09013. 83 pp. http://www2.gov.bc.ca/gov/content/industry/natural-resource-use/land-use/fossilmanagement/mcabee 
652 Roth, J.L., and Dilcher, D.L., 1978. Some considerations in leaf size and leaf margin analysis of 653 fossil leaves. Courier Forschungsinstitut Senckenberg, 30: 165-171.

654 Royer, D.L., Osborne, C.P. and Beerling, D.J., 2002. High $\mathrm{CO}_{2}$ increases the freezing sensitivity 655 656 of plants: Implications for paleoclimatic reconstructions from fossil floras. Geology, 30(11): 963-966.

657 Royer, D.L., Peppe, D.J., Wheeler, E.A., and Niinemets, Ü. 2012. Roles of climate and 658 659 660 661 functional traits in controlling toothed vs. untoothed leaf margins. American Journal of Botany, 99: 915-922.

Sack, L., Scoffoni, C., McKown, A. D., Frole, K., Rawls, M., Havran, J. C., Tran, H., and Tran, T. 2012. Developmentally based scaling of leaf venation architecture explains global ecological patterns. Nature Communications, 3: 837.

Schubert, B.A., and Jahren, A.H. 2011. Quantifying seasonal precipitation using high-resolution carbon isotope analyses in evergreen wood. Geochimica et Cosmochimica Acta, 75(22): $7291-7303$.

666

Smith, R.Y. 2011. The Eocene Falkland fossil flora, Okanagan Highlands, British Columbia: paleoclimate and plant community dynamics during the early Eocene climatic optimum. Ph.D. Dissertation, Department of Geological Sciences, The University of Saskatchewan,

670 Smith, R.Y., Basinger, J.F., and Greenwood, D.R. 2009. Depositional setting, fossil flora, and paleoenvironment of the Early Eocene Falkland site, Okanagan Highlands, British Columbia. Canadian Journal of Earth Sciences, 46(11): 811 - 822. doi: 10.1139/E09-053 
673 Smith, R.Y., Greenwood, D.R., and Basinger, J.F. 2010. Estimating paleoatmospheric $p \mathrm{CO}_{2}$

674 during the Early Eocene Climatic Optimum from stomatal frequency of Ginkgo,

675 'Okanagan Highlands', British Columbia, Canada. Paleogeography, Paleoclimatology,

676 Paleoecology, 295(1-2): 120-131. doi: 10.1007/s12549-011-0061-5

677 Smith, R.Y., Basinger, J.F., and Greenwood, D.R. 2012. Early Eocene plant diversity and

678 dynamics in the Falkland flora, Okanagan Highlands, British Columbia, Canada.

679

680 Palaeobiodiversity and Palaeoenvironments 92(3): 309-328. doi: 10.1007/s12549-011-

681

Spicer, R.A., 2000. Leaf physiognomy and climate change. In Biotic Response to Global change: the Last 145 Million Years. Edited by S.J. Culver and P. Rawson. Cambridge University Press, Cambridge, pp. 244-264.

684

Spicer, R.A., Herman, A.B., and Kennedy, E.M. 2004. The foliar physiognomic record of 685 686 climatic conditions during dormancy: CLAMP and the Cold Month Mean Temperature. Journal of Geology, 112: 685-702.

687 688 689 690 691 692 693 694

\section{1-5}

Spicer, R.A., Herman, A.B., Kennedy, E.M. 2005. The sensitivity of CLAMP to taphonomic loss of foliar physiognomic characters. Palaios, 20: 429-438.

Spicer, R.A., Valdes, P.J., Spicer, T.E.V., Craggs, H.J., Srivastava, G., Mehrotra, R.C., Yang, J., 2009. New developments in CLAMP: Calibration using global gridded meteorological data. Palaeogeography, Palaeoclimatology, Palaeoecology, 283: 91-98.

Steart, D.C., Boon, P.I., Greenwood, D.R., and Diamond, N.T. 2002. Transport of leaf litter in upland streams of Eucalyptus and Nothofagus forests in south-eastern Australia. Archiv für Hydrobiologie, 156(1): 43-61. doi: 10.1127/0003-9136/2002/0156-0043 
695 Tribe, S. 2005. Eocene paleo-physiography and drainage directions, southern Interior Plateau, 696 British Columbia. Canadian Journal of Earth Sciences, 42(2): 215-230.

697 Verschoor, K. van R. 1974. Paleobotany of the Tertiary (Early Middle Eocene) McAbee Beds, 698 British Columbia. M.Sc. thesis, Geology Department, University of Calgary, Calgary, 699 Alberta, Canada.

700

701

702

703

704

705

706

707

708

709

710

711

712

713

714

715

Walther, G.R., Gritti, E.S., Berger, S., Hickler, T., Tang, Z., and Sykes, M.T. 2007. Palms tracking climate change. Global Ecology and Biogeography, 16: 801-809.

West, C.K., Greenwood, D.R., and Basinger, J.F. 2015. Was the Arctic Eocene 'rainforest' monsoonal? Estimates of seasonal precipitation from early Eocene megafloras from Ellesmere Island, Nunavut. Earth \& Planetary Science Letters, 427: 18 - 30.

Wilf, P. 1997. When are leaves good thermometers?: A new case for Leaf Margin Analysis. Paleobiology, 23: 373-390.

Wilf, P., Wing, S.L., Greenwood, D.R., and Greenwood, C.L. 1998. Using fossil leaves as paleoprecipitation indicators: an Eocene example. Geology, 26(3): 203-206. doi: 10.1130/0091-7613(1998)0262.3.CO;2

Wilf, P., Cúneo, N.R., Johnson, K.R., Hicks, J F., Wing, S.L., and Obradovich, J.D. 2003. High plant diversity in Eocene South America: evidence from Patagonia. Science, 300: 122125.

Wilf, P., Johnson, K.R., Cúneo, N.R., Smith, M.E., Singer, B.S., and Gandolfo, M.A. 2005. Eocene plant diversity at Laguna del Hunco and Río Pichileufú, Patagonia, Argentina: American Naturalist, 165: 634-650. 
716

717

718

719

720

721

722

723

724

725

726

727

728

729

730

731

732

733

734

735

736

Wilson, M.V.H. 1977. Middle Eocene freshwater fishes from British Columbia. Life Sciences Contributions, Royal Ontario Museum, No. 113, 61 pp.

Wilson, M.V.H. 2008. McAbee Fossil Site Assessment, Revised August 5, 2007 and October 24, 2008; unpubl.report, British Columbia Ministry of Agriculture and Lands, 60 p. http://www2.gov.bc.ca/gov/content/industry/natural-resource-use/land-use/fossilmanagement/mcabee

Wilson, M.V.H., and Bogen, A. 1994. Tests of the annual hypothesis and temporal calibration of a 6375-varve fish-bearing interval, Eocene Horsefly Beds, British Columbia, Canada. Historical Biology, 7: 325-339.

Wing, S.L., and Greenwood, D.R. 1993. Fossils and fossil climate: the case for equable continental interiors in the Eocene. Philosophical Transactions of the Royal Society of London. Series B: Biological Sciences, 341(1297): 243-252. doi: 10.1098/rstb.1993.0109

Wolfe, J.A. 1979. Temperature parameters of Humid to Mesic Forests of Eastern Asia and relation to forests of other regions of the Northern Hemisphere and Australasia. United States Geological Survey Professional Paper, 1106: 1-37.

Wolfe, J. A. 1993. A method of obtaining climatic parameters from leaf assemblages. U.S. Geological Survey Bulletin, 2040: 1-71.

Wolfe, J.A., 1995. Paleoclimatic estimates from Tertiary leaf assemblages. Ann. Rev. Earth Planet Sci., 23:119-142.

Wolfe, J.A., Schorn, H.E., Forest, C.E., and Molnar, P. 1997. Paleobotanical evidence for high altitudes in Nevada during the Miocene. Science, 276: 1672-1675. 
737 Wolfe, J.A., Forest, C.E., and Molnar, P. 1998. Paleobotanical evidence of Eocene and 738 Oligocene paleoaltitudes in midlatitude western North America. Geological Society of $739 \quad$ America Bulletin, 110: 664-678.

740 Yang, J., Spicer, R A., Spicer, T.E., and Li, C.S. 2011. 'CLAMP Online': a new web-based 741 paleoclimate tool and its application to the terrestrial Paleogene and Neogene of North $742 \quad$ America. Paleobiodiversity and Paleoenvironments, 91: 163-183.

743 Yang, J., Spicer, R.A., Spicer, T.E., Arens, N.C., Jacques, F., Su, T., Kennedy, E.M., Herman, 744 A.B., Steart, D.C., Srivastava, G. and Mehrotra, R.C., 2015. Leaf form-climate 745 relationships on the global stage: an ensemble of characters. Global Ecology and Biogeography, 24(10): 1113-1125.

747 Zachos, J.C., Dickens, G.R., and Zeebe, R. E. 2008. An early Cenozoic perspective on greenhouse warming and carbon-cycle dynamics. Nature, 451: 279-283. Climatolology, 28: 1563-1578. 


\section{$1 \quad$ Figure Captions}

2 Fig. 1. Map of British Columbia showing the Early Eocene Okanagan Highlands fossil sites

3 (open circles) and nearby cities (small filled circles). Star signifies the study area. Modified from

$4 \quad$ Dillhoff et al. (2013; Fig. 1).

5 Fig. 2. (A-C) The McAbee fossil beds site (taken 2005 and 2015). (A) View of main beds from

6 highway (2005). Dotted line indicates outcrop exposure following a road that was cut into the

7 lake sediments (approx. $0.5 \mathrm{~km}$ ). Approximate locations of the sampling sites for the University

8 of Saskatchewan (US) and Brandon University collections (BU) are shown, as is the location of

91 of 2 quarries sampled in 2015 (see (A) and (B) in this Figure). White stars indicate exposures

10 favoured by mine operators (Read and Hebda 2009; Hebda 2012), and the likely source of fossils

11 featured in reports of fossils collected after the road was constructed and curated in the

12 Thompson Rivers University collection. The prominent hoodoos above the McAbee beds are

13 weathered volcanics of the Dewdrop Formation. (B) Closer view of 2015 Quarry 1 site showing

14 bench cut for quantitative 'census-style' sampling (dashed line), and prominent ash layer (arrow).

15 Note red flagging tape marking location of a steel peg marker (= GPS point) near a hammer to

16 the right of the man, and hoodoos above. (C) Close up view of beds sampled at red flagging tape

17 shown in (B) and ash layer (arrow) used for dating (Moss et al. 2005).

18 Fig. 3. Synthetic or 'ideal' site stratigraphy based on lithological descriptions from Hebda (2012),

19 showing approximate stratigraphic location of the US and BU historical collections, and sections

202 and 3 (numbering from Hebda 2012) reconstructed for the 2 separate quarries where these

21 collections were made. 
22 Fig. 4. (A-H) Examples of the leaf morphotypes from both collections I. MA0xx = McAbee leaf 23 morphotype. (A \& B) MA016 Sassafras hesperia; C, MA031 Acer sp.; D, MA029 Betula

24 leopoldae; E, MA006 cf. Vitis; F, MA033 cf. Crataegus; G, MA019 cf. Bignoniaceae; H, 25 MA036 cf. Decodon. Scale bar $=1 \mathrm{~cm}$.

26 Fig. 5. (A-I) Examples of the leaf morphotypes from both collections II. MA0xx = McAbee leaf 27 morphotype. (A) MA001 Fagus langevenii. (B) MA022 cf. Fraxinus. (C \& F) MA017

28 Comptonia columbiana. (D) MA040 unknown leaf type. (E) MA002 unknown leaf type. (G)

29 MA027 cf. Platanaceae. (H) MA036 unknown leaf type. (I) MA003 Ulmus okanaganesis. Scale 30 bar $=1 \mathrm{~cm}$.

31 Fig. 6. The BU collection (filled circle) and combined collection (filled square) in relation to 32 modern data points in the CLAMP ordination using Canonical Correspondence Analysis (CCA axes 1 vs. 2). Groups Monsoonal A and Monsoonal B show modern monsoonal climates within 34 the cloud. Monsoonal A represents modern arid to median climates (Arizona, California, Puerto Rico). Monsoonal B represents humid climates (Southern Japan, Tropical Pacific Islands).

36 Ungrouped data represents the range of modern non-monsoonal environments. Main

37 environmental vectors are plotted as labelled arrows. Labels are as follows going clockwise (Yang et al. 2011): WMMT- warm month mean temperature, GROWSEAS- growing season, 39 MAT- mean annual temperature, CMMT- cold month mean temperature, ENTHAL- enthalpy, SH- specific humidity, GSP- growing season precipitation, MMGSP- mean month growing 41 season precipitation, THREE_DRY-precipitation of the three driest months, THREE_WET42 precipitation of the three wettest months, RH- relative humidity. 
Table 1. The leaf morphotypes which are found in both collections, the Brandon University collection, and the University of Saskatchewan collection, and where known identified to genus or species.

\begin{tabular}{|c|c|c|}
\hline \multirow{2}{*}{ Both Collections } & \multirow{2}{*}{$\begin{array}{l}\text { Brandon University } \\
\text { Collection }\end{array}$} & \multirow{2}{*}{$\begin{array}{l}\text { University of Saskatchewan } \\
\text { Collection }\end{array}$} \\
\hline & & \\
\hline MA 001- Fagus langevinii & MA 004 & MA 041-Cercidiphyllum / Joffrea \\
\hline MA 002 & MA 005 & MA 042 \\
\hline MA 003 - Ulmus okanaganensis & MA 007 - cf. Neviusia & MA 043 \\
\hline MA 006 - cf. Vitis & MA 008 & \\
\hline MA 016 - Sassafras hesperia & MA 009 & \\
\hline MA 018 & MA 010 & \\
\hline MA 022 - cf. Fraxinus & MA 011 - Comptonia columbiana & \\
\hline MA 026 & MA 012 & \\
\hline MA 029 - Betula leopoldae & MA 013 & \\
\hline MA 032 & MA 014 & \\
\hline \multirow{10}{*}{ MA 033 - Crataegus sp. } & MA 015 & \\
\hline & MA 017 & \\
\hline & MA 019 - cf. Bignoniaceae & \\
\hline & MA 020 & \\
\hline & MA 021 & \\
\hline & MA 023 & \\
\hline & MA 024 & \\
\hline & MA 025 & \\
\hline & MA 027 - cf. Platanaceae & \\
\hline & MA 028 - cf. Tetracentron & \\
\hline
\end{tabular}


MA 030

MA 031- Acer $s p$.

MA 034

MA 035

MA 036 - Decodon $s p$.

MA 037

MA 038

MA 039

MA 040 
Table 2. One way ANOVA for all fossils in the Brandon University and University of Saskatchewan collections. Column 1- Brandon University Collection, Column 2- University of Saskatchewan collection, SS- sum of squares, df- degrees of freedom, MS, mean square between groups.

Anova: Single Factor

SUMMARY

\begin{tabular}{crrrr}
\hline Groups & Count & Sum & Average & Variance \\
& & & & \\
\hline Column 1 & 40 & 74108 & 1852.7 & 2159686 \\
Column 2 & 14 & 17988 & 1284.857 & 375308 \\
\hline
\end{tabular}

ANOVA

Source of

Variation

$S S$

df $\quad M S$

F

P-value $\quad F$ crit

Between

Groups

3343879

$1 \quad 3343879 \quad 1.951387$

0.168371

4.026631

Within Groups $\quad 89106744 \quad 52 \quad 1713591$

Total

92450623

53 
Table 3. One way ANOVA for complete fossils in the Brandon University and University of Saskatchewan collections. Column 1- Brandon University Collection, Column 2- University of Saskatchewan collection, SS- sum of squares, df- degrees of freedom, MS, mean square between groups.

Anova: Single Factor

SUMMARY

\begin{tabular}{rrrrr}
\hline Groups & Count & Sum & Average & Variance \\
& & & & \\
\hline Column 1 & 28 & 55200 & 1971.429 & 2849242 \\
Column 2 & 8 & 8339 & 1042.375 & 568252.6 \\
\hline
\end{tabular}

ANOVA

Source of

Variation

$S S$

df $\quad M S$

F

P-value $\quad$ F crit

Between

Groups

5370652

$1 \quad 5370652 \quad 2.256931$

0.142249

4.130018

Within Groups $\quad 80907297 \quad 34 \quad 2379626$

Total

86277949 35 
Table 4. Results for Leaf Margin Analysis and Leaf Area Analysis for the Brandon University collection and the combined collection compared to published data on the University of Saskatchewan collection from Greenwood and Wing (1995).

\begin{tabular}{|c|c|c|c|c|c|c|}
\hline Equation & Variable & $\begin{array}{l}\text { Values } \\
\text { BU } \\
\text { collection }\end{array}$ & $\begin{array}{l}\text { Estimates } \\
\text { BU } \\
\text { collection }\end{array}$ & $\begin{array}{l}\text { Greenwood } \\
\text { and Wing } \\
1995 \text { US } \\
\text { collection }\end{array}$ & $\begin{array}{l}\text { Values } \\
\text { combined } \\
\text { collection }\end{array}$ & $\begin{array}{l}\text { Estimates } \\
\text { combined } \\
\text { collection }\end{array}$ \\
\hline LMA- (2) & MAT & $\begin{array}{l}\text { LMP 23\% } \\
\text { non-toothed }\end{array}$ & $8.2 \pm 2.0^{\circ} \mathrm{C}$ & $\begin{array}{l}{ }^{a} 10.1 \pm 2.0 \\
{ }^{\circ} \mathrm{C}\end{array}$ & $\begin{array}{l}\text { LMP } 26 \% \\
\text { non-toothed }\end{array}$ & $9.2 \pm 2.0^{\circ} \mathrm{C}$ \\
\hline LMA- (3) & MAT & $\begin{array}{l}\text { LMP 23\% } \\
\text { non-toothed }\end{array}$ & $9.3 \pm 4.8^{\circ} \mathrm{C}$ & $\begin{array}{l}{ }^{b} 12.8 \pm 4.8 \\
{ }^{\circ} \mathrm{C}\end{array}$ & $\begin{array}{l}\text { LMP } 26 \% \\
\text { non-toothed }\end{array}$ & $9.9 \pm 4.8^{\circ} \mathrm{C}$ \\
\hline $\begin{array}{l}\text { LAA- } \\
\text { Indirect (4) }\end{array}$ & MAP & MLnA 7.3 & $\begin{array}{l}117 \mathrm{~cm} \cdot \mathrm{a}^{-1}- \\
35,+51\end{array}$ & N/A & MLnA 7.3 & $\begin{array}{l}116 \mathrm{~cm} \cdot \mathrm{a}^{-1} \\
-35,+50\end{array}$ \\
\hline $\begin{array}{l}\text { LAA- Direct } \\
\text { (4) }\end{array}$ & MAP & MLnA 7.1 & $\begin{array}{l}105 \mathrm{~cm} \cdot \mathrm{a}^{-1}- \\
32,+45\end{array}$ & $\begin{array}{l}c 99 \mathrm{~cm} \cdot \mathrm{a}^{-1} \\
-30,+43\end{array}$ & MLnA 7.1 & $\begin{array}{l}104 \mathrm{~cm} \cdot \mathrm{a}^{-1} \\
-31,+45\end{array}$ \\
\hline $\begin{array}{l}\text { LAA-Direct } \\
\text { (5) }\end{array}$ & MAP & MLnA 7.1 & $\begin{array}{l}137 \mathrm{~cm} \cdot \mathrm{a}^{-1}- \\
63+116\end{array}$ & $\mathrm{~N} / \mathrm{A}$ & MLnA 7.1 & $\begin{array}{l}137 \mathrm{~cm} \cdot \mathrm{a}^{-1}- \\
63,+116\end{array}$ \\
\hline
\end{tabular}

${ }^{a}$ new estimate using LMP data from Greenwood and Wing (1995) from the US collection

${ }^{b}$ new estimate using LMP data from Greenwood and Wing (1995) from the US collection

${ }^{c}$ estimate reported in Dillhoff et al. (2013) from the US collection 
Table 5. Results from CLAMP analysis for the Brandon University collection and 'Combined collection'. 5a, temperature estimates; $\mathbf{5 b}$, seasonal precipitation; 5c, additional precipitation and humidity variable estimates.

(5a)

\begin{tabular}{llll}
\hline Collection & Mean Annual & Warm Month Mean & Cold Month Mean \\
& Temperature & Temperature & Temperature \\
\hline Brandon & $13.1^{\circ} \mathrm{C} \pm 2.1$ & $21.0^{\circ} \mathrm{C} \pm 2.5$ & $5.0^{\circ} \mathrm{C} \pm 3.4$ \\
Combined & $12.9^{\circ} \mathrm{C} \pm 2.1$ & $20.5^{\circ} \mathrm{C} \pm 2.5$ & $5.1^{\circ} \mathrm{C} \pm 3.4$ \\
\hline
\end{tabular}

(5b)

\begin{tabular}{llll}
\hline Collection & Growing Season & Growing Season & Mean Month Growing \\
& & Precipitation & Season Precipitation \\
\hline Brandon & 7.7 Months \pm 1.1 & $130 \mathrm{~cm} \pm 32$ & $18 \mathrm{~cm} \pm 4$ \\
Combined & 7.6 Months \pm 1.1 & $130 \mathrm{~cm} \pm 32$ & $17 \mathrm{~cm} \pm 4$ \\
\hline
\end{tabular}

$(5 \mathrm{c})$

\begin{tabular}{lllll}
\hline Collection & Three Wet & Three Dry & Relative & Specific \\
& Months & Months & Humidity & Humidity \\
\hline Brandon & $60 \mathrm{~cm} \pm 23$ & $31 \mathrm{~cm} \pm 6$ & $84.4 \% \pm 8.6$ & $12.5{\mathrm{~g} \cdot \mathrm{kg}^{-1} \pm 1.7}$ \\
Combined & $62 \mathrm{~cm} \pm 23$ & $30 \mathrm{~cm} \pm 6$ & $84.4 \% \pm 8.6$ & $12.2{\mathrm{~g} \cdot \mathrm{kg}^{-1} \pm 1.7}$ \\
\hline
\end{tabular}




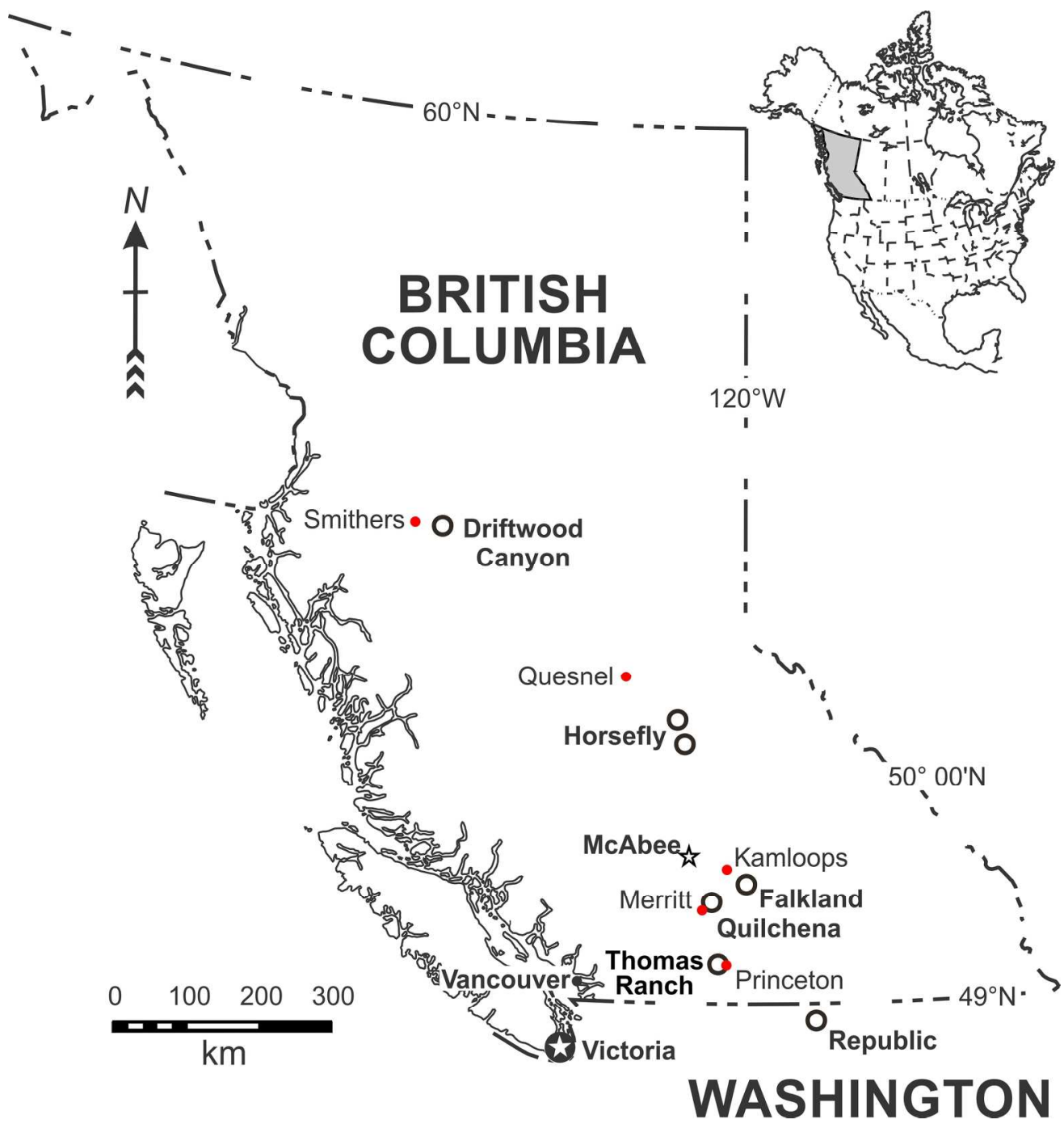

Fig. 1. Map of British Columbia showing the Early Eocene Okanagan Highlands fossil sites (open circles) and nearby cities (small filled circles). Star signifies the study area. Modified from Dillhoff et al. (2013; Fig. 1). $90 \times 95 \mathrm{~mm}(600 \times 600 \mathrm{DPI})$ 

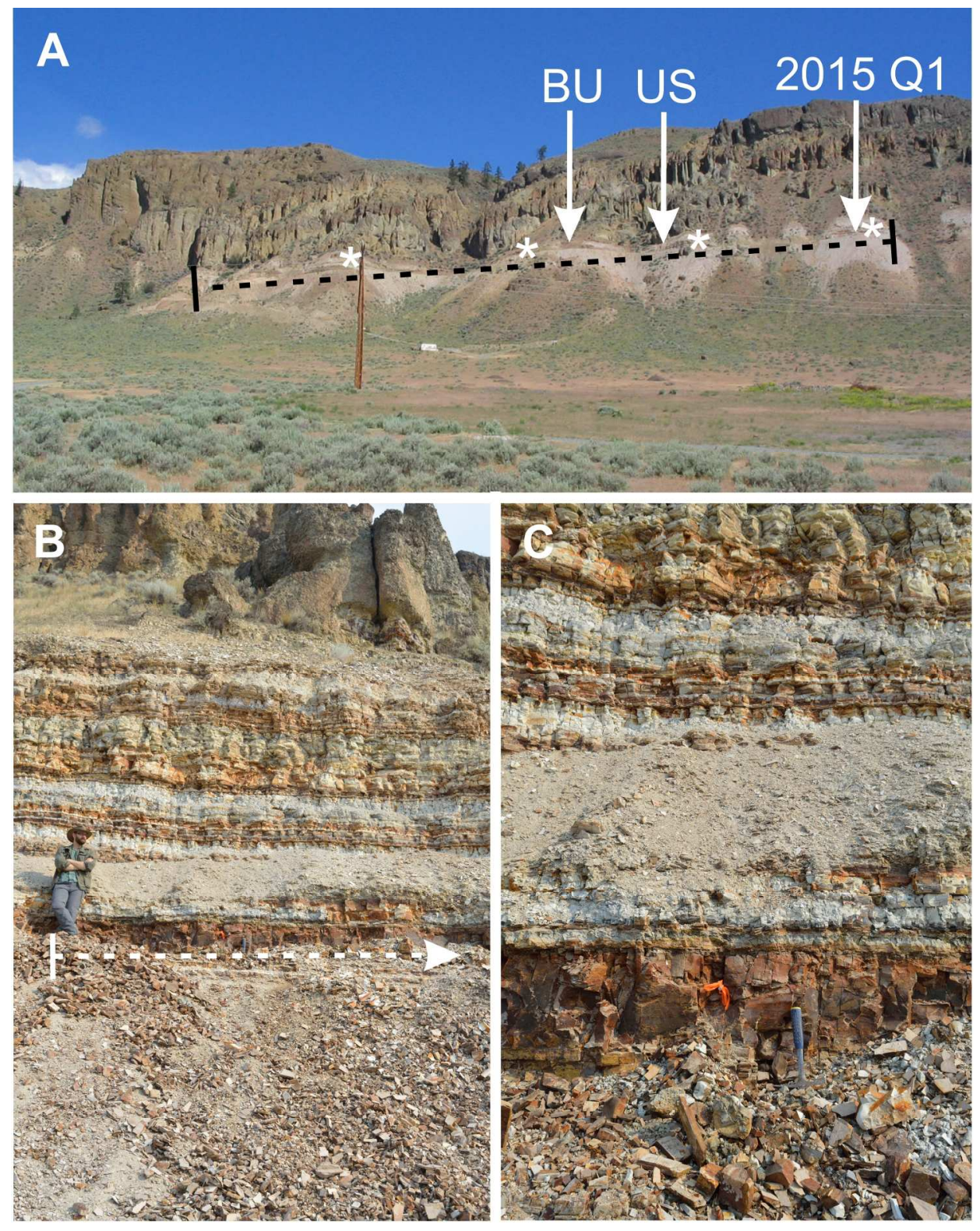

Fig. 2. (A-C) The McAbee fossil beds site (taken 2005 and 2015). (A) View of main beds from highway

(2005). Dotted line indicates outcrop exposure following a road that was cut into the lake sediments (approx. $0.5 \mathrm{~km}$ ). Approximate locations of the sampling sites for the University of Saskatchewan (US) and Brandon University collections (BU) are shown, as is the location of 1 of 2 quarries sampled in 2015 (see (A) and (B) in this Figure). White stars indicate exposures favoured by mine operators (Read and Hebda 2009;

Hebda 2012), and the likely source of fossils featured in reports of fossils collected after the road was constructed and curated in the Thompson Rivers University collection. The prominent hoodoos above the McAbee beds are weathered volcanics of the Dewdrop Formation. (B) Closer view of 2015 Quarry 1 site showing bench cut for quantitative 'census-style' sampling (dashed line), and prominent ash layer (arrow). Note red flagging tape marking location of a steel peg marker (= GPS point) near a hammer to the right of the man, and hoodoos above. (C) Close up view of beds sampled at red flagging tape shown in (B) and ash layer (arrow) used for dating (Moss et al. 2005).

$179 \times 226 \mathrm{~mm}(300 \times 300 \mathrm{DPI})$ 


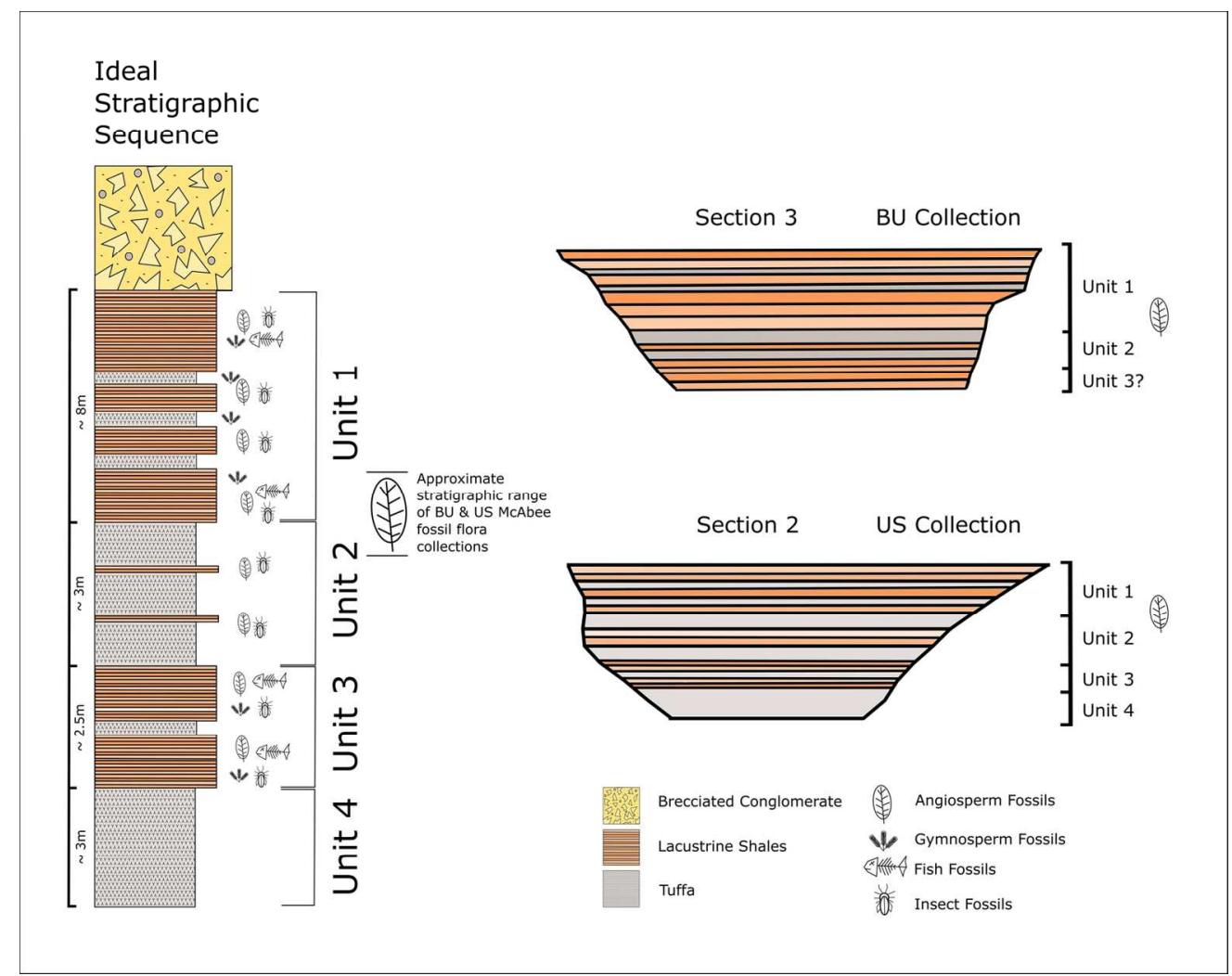

Fig.3. Synthetic or ideal site stratigraphy based on the lithological descriptions from Hebda (2012), showing approximate stratigraphic location of the US and BU historical collections, and sections 2 and 3 (numbering from Hebda 2012) reconstructed for the 2 separate quarries where these collections were made. $73 \times 58 \mathrm{~mm}(600 \times 600 \mathrm{DPI})$ 


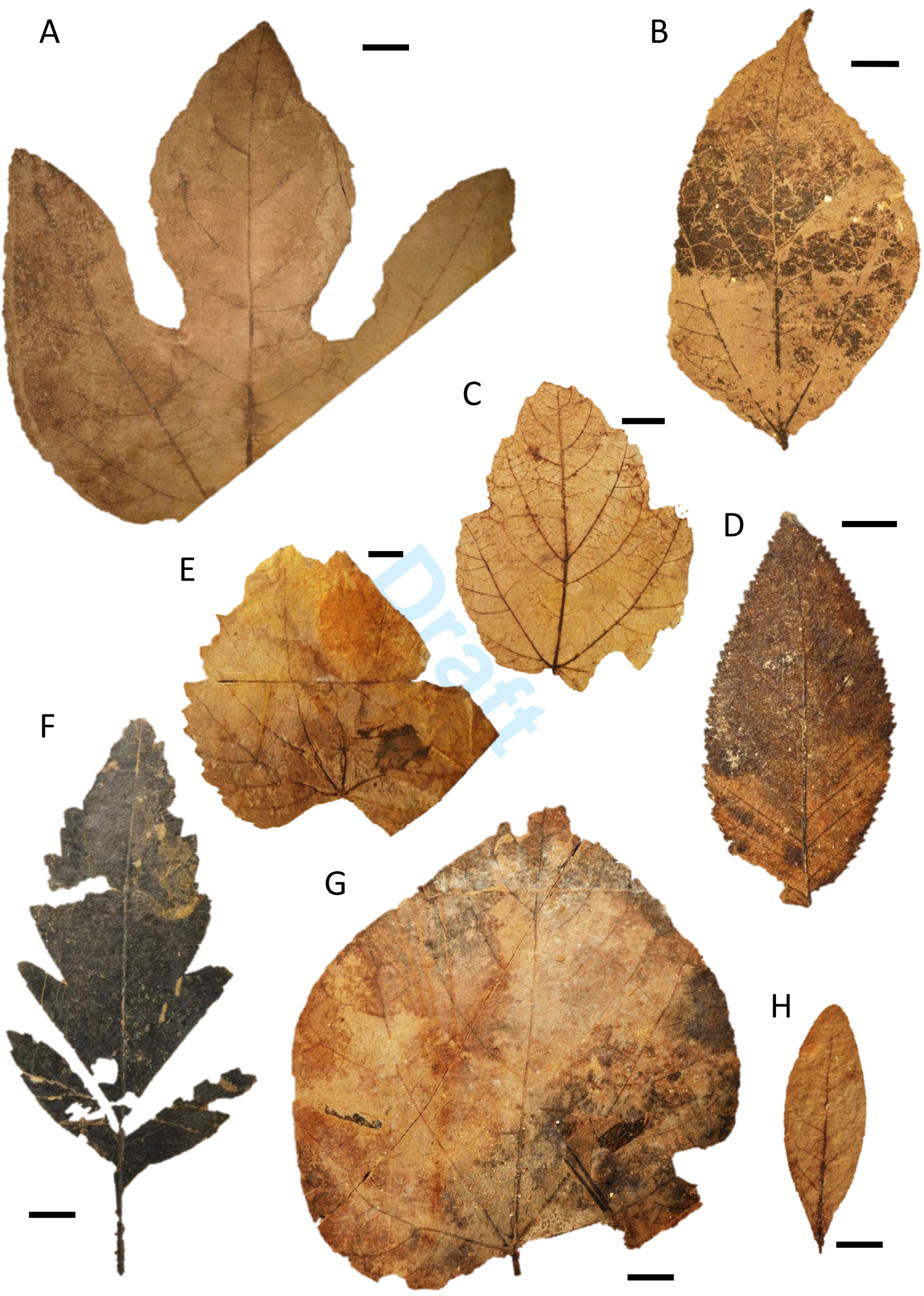

https://mc06.manuscriptcentral.com/cjes-pubs 


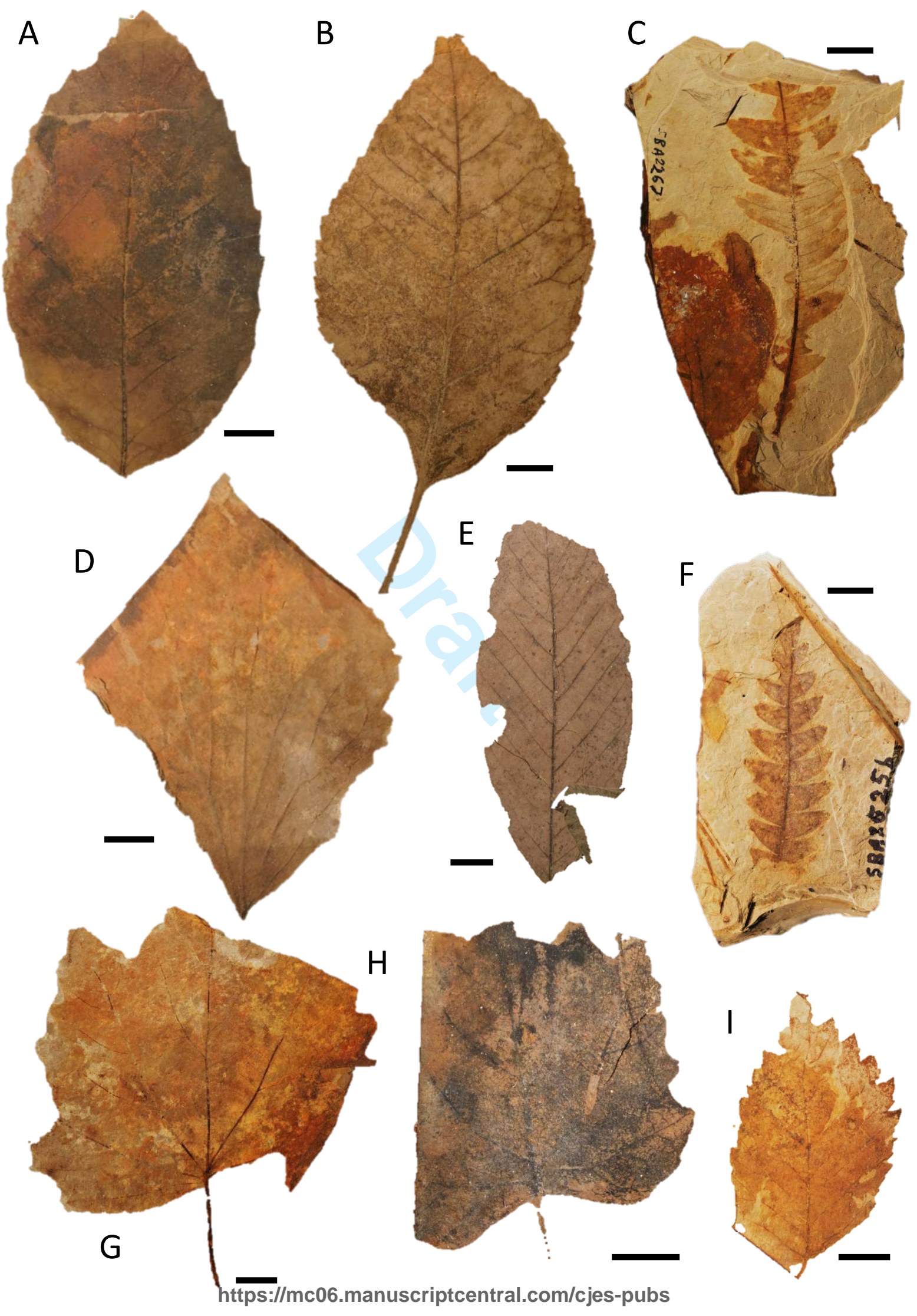




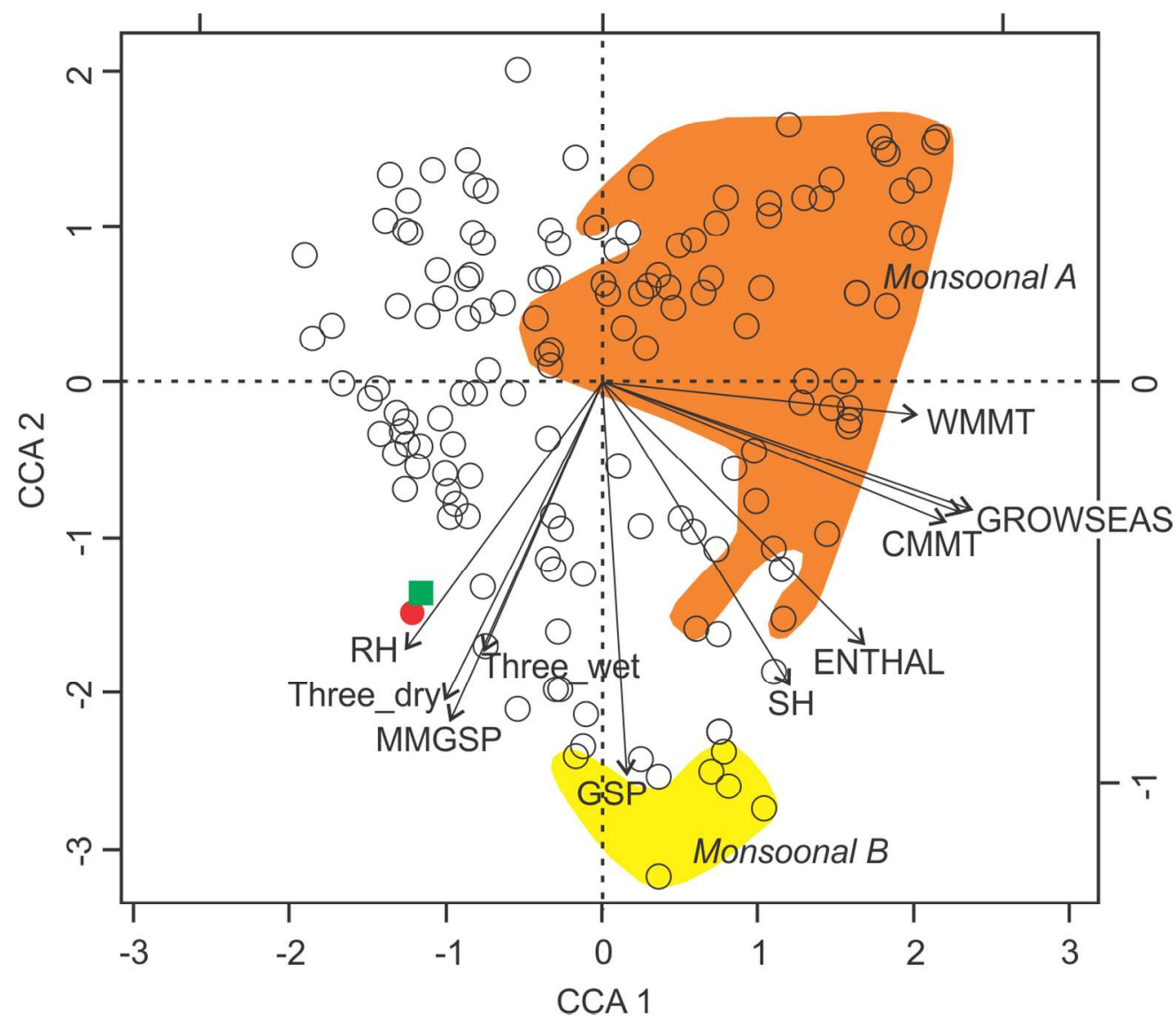

Fig. 6. The BU collection (filled circle) and combined collection (filled square) in relation to modern data points in the CLAMP ordination using Canonical Correspondence Analysis (CCA axes 1 vs. 2). Groups Monsoonal A and Monsoonal B show modern monsoonal climates within the cloud. Monsoonal A represents modern arid to median climates (Arizona, California, Puerto Rico). Monsoonal B represents humid climates (Southern Japan, Tropical Pacific Islands). Ungrouped data represents the range of modern non-monsoonal environments. Main environmental vectors are plotted as labelled arrows. Labels are as follows going clockwise (Yang et al. 2011): WMMT- warm month mean temperature, GROWSEAS- growing season, MATmean annual temperature, CMMT- cold month mean temperature, ENTHAL- enthalpy, SH- specific humidity, GSP- growing season precipitation, MMGSP- mean month growing season precipitation, THREE_DRYprecipitation of the three driest months, THREE_WET- precipitation of the three wettest months, RH- relative humidity.

$121 \times 105 \mathrm{~mm}(300 \times 300 \mathrm{DPI})$ 